WITOLD JARNO

UNIWERSYTET ŁÓDZKI*

\title{
Zarys wojskowych dziejów Tomasza Mazowieckiego w latach II Rzeczypospolitej
}

Tomaszów Mazowiecki ${ }^{1}$ - noszący do sierpnia 1926 r. nazwę Tomaszów Rawski - został założony przez hrabiego Antoniego Ostrowskiego pod koniec XVIII w., a 6 lipca 1830 r. uzyskał prawa miejskie. Miasto intensywnie rozbudowywało się w XIX w., stając się ważnym ośrodkiem przemysłu włókienniczego na obszarze Guberni Piotrkowskiej, powstałej w 1867 r. Pod względem administracyjnym miasto było częścia powiatu brzezińskiego, wchodzącego aż do czasu wybuchu I wojny światowej w skład wspomnianej guberni $^{3}$. $Z$ uwagi na rosnące znaczenie gospodarcze Tomaszowa pod koniec XIX w. stacjonowały w nim czasowo oddziały wojsk rosyjskich (np. pododdziały 27. Witebskiego pp z 7. Dywizji Piechoty), dajac poczatek garnizonowi tomaszowskiemu.

W latach I wojny światowej Tomaszów Mazowiecki znalazł się pod okupacja niemiecka. W tym czasie władze niemieckie prowadziły rabunkowa gospodarkę, pogłębiającą nędzę i głód ludności miasta. $Z$ uwagi na narastanie nastrojów antyniemieckich stacjo-

* Wydział Filozoficzno-Historyczny, Instytut Historii, Katedra Historii Polski i Świata po 1945 r.

1 W tekście użyto następujące skróty: AMTM - Akta Miasta Tomaszowa Mazowieckiego, APT - Archiwum Państwowe w Piotrkowie Trybunalskim Oddział w Tomaszowie Mazowieckim, CAW - Centralne Archiwum Wojskowe, OGE Okręg Generalny Łódź, OK IV - Okręg Korpusu nr IV Łódź - pułk Artylerii ciężkiej, PKU - Powiatowa Komenda Uzupełnień, POW - Polska Organizacja Wojskowa, pp - pułk piechoty, pSK - Pułk Strzelców Kaniowskich.

2 „Monitor Polski” 1926, nr 196, poz. 561. W tekście będzie używana nazwa Tomaszów Mazowiecki w odniesieniu do całego okresu międzywojennego.

3 Szerzej o historii Tomaszowa Mazowieckiego por. Tomaszów Mazowiecki. Dzieje miasta, red. B. Wachowska, Warszawa-Lódź 1980. 
nowały w nim niemieckie oddziały Landszturmu (pospolitego ruszenia). Dla ich potrzeb zaadaptowano na cele koszarowe budynki przy ul. Pilicznej 12 i 14 (obecnie ul. Ignacego Mościckiego). Jesienia 1918 r. zakwaterowano w nich 2. kompanię Rybnickiego Batalionu Piechoty Landszturmu (batalionem tym dowodził w latach 1915-1918 mjr Schmidt, imię nieznane). Batalion ten w październiku 1918 r. liczył 1040 żołnierzy zgrupowanych w pięciu kompaniach, co dawało średnio po około 200 żołnierzy w każdej $z$ nich. Niemiecka nazwa batalionu brzmiała: Landsturm Infanterie Batalion „Rybnik” VI/19 - toteż warto ją wyjaśnić. Rzymska VI określała, że został on sformowany na obszarze niemieckiego Okręgu Korpusu nr VI Wrocław (niemiecki Breslau), a arabska liczba 19 - kolejność formowania batalionów na obszarze tego okręgu. Niemiecka nazwa batalionu oznaczała, że został on sformowany w Rybniku, jako 19. batalion Landszturmu na terenie Wrocławskiego Okręgu Korpusu. Batalion w latach 1915-1918 stacjonował w rejonie Koluszek, a dowództwo w pobliskich Żakowicach. Wspomniana 2. kompania (dowodzona przez por. Keisera, imię nieznane) przybyła do Tomaszowa Mazowieckiego prawdopodobnie w lutym 1918 r., po burzliwych demonstracjach ulicznych na wieść o podpisaniu traktatu brzeskiego przyznajacego Chełmszczyznę Ukrainie. Z kolei w pobliskiej Spale kwaterowała część 3. kompanii ${ }^{4}$ 2. Batalionu Piechoty Landszturmu „Schroda” V/18 (batalion ten został sformowany na obszarze niemieckiego Okręgu Korpusu nr V Poznań). Ponadto w Tomaszowie Mazowieckim znajdowały się także niemiecka Komendantura Wojskowa (w 1918 r. na jej czele stał kpt. Neussa, imię nieznane) przy ul. Pałacowej 7 (obecnie ul. POW) oraz niewielki pododdział niemieckiej żandarmerii polowej ${ }^{5}$.

W latach I wojny światowej w Tomaszowie Mazowieckim stopniowo rozwijały działalność polskie organizacje paramilitarne, spośród których największą była powstała w 1915 r. lokalna komórka POW. W szczytowym momencie swego rozwoju liczyła około 100 ludzi. Organizacyjnie podlegała komendantowi Obwodu Brzezińskiego POW, którym był Mieczysław Zych Mackiewicz. Z kolei stanowisko komendanta POW w Tomaszowie Mazowieckim i zarazem

4 Pozostała część owej kompanii stacjonowała jesienia 1918 r. w Burzeninie koło Sieradza.

5 W. Ru dź, Tomaszowa Mazowieckiego droga do niepodległości 1914-1918, Tomaszów Mazowiecki 1988, s. 6-8; J. S z c z e pań s ki, Landszturm w Generalnym Gubernatorstwie Warszawskim 1915-1918. Formacja głębokich rezerw, Warszawa 2012, s. 107 i 242-244. 
dowódcy 2. kompanii POW zajmował od 29 października 1917 r. Roman Tuchowski6. Miejscowa POW opierała się na byłych legionistach oraz skautach, którzy w listopadzie 1918 r. stanowili główna siłę w akcji rozbrajania Niemców w mieście 7 .

Listopad 1918 r. przyniósł nie tylko zakończenie działań wojennych na frontach I wojny światowej, lecz także odrodzenie państwa polskiego. Proces powstawania Wojska Polskiego nabrał tempa już w październiku, więc jeszcze za czasów Rady Regencyjnej. Po rezygnacji gen. Hansa Hartwiga von Beselera ze stanowiska Naczelnego Wodza Polskiej Siły Zbrojnej Rada przejęła faktyczne kierownictwo nad tworzona armią. Dzięki temu 25 października powstał Sztab Generalny Wojska Polskiego, a następnego dnia Ministerstwo Spraw Wojskowych. Podjęto również przygotowania do rozbudowy polskich sił wojskowych na obszarze podległym Radzie Regencyjnej, który 30 października podzielono na 15 okręgów wojskowych - miano w nich przystapić do formowania piechoty terytorialnej. Jednym $z$ nich był VIII Okręg Wojskowy $z$ siedziba w Łodzi (dowódca - płk Albin Jasiński) obejmujący Łódź oraz powiaty łaski, łódzki i brzeziński, więc także Tomaszów Mazowiecki. Na wieść o zawarciu rozejmu w Compiègne (11 listopada) i podjęciu przez Polaków akcji rozbrajania Niemców na ziemiach dawnej Kongresówki Rada Regencyjna przekazała tego dnia Józefowi Piłsudskiemu zwierzchnictwo nad wojskiem, a 14 listopada całą swoją władzę 8 .

Wrzenie ogarnęło w tych dniach także Tomaszów Mazowiecki. Wieści o rewolucji w Berlinie i zawarciu rozejmu doprowadziły do osłabienia dyscypliny wśród żołnierzy niemieckich stacjonujących na całym obszarze dawnej Kongresówki. Napięta sytuację tych dni

6 Szerzej o Romanie Tuchowskim por. A. W o skow ski, Harcerstwo $w$ Tomaszowie Mazowieckim w latach 1911-1918, Tomaszów 1987, s. 111-116; A. W ró b e 1, Roman Tuchowski 1896-1979 - od goracego patrioty do zagorzałego komunisty (tekst w druku).

7 W. Rudź, op. cit., s. 6-8.

8 W. Kozłow s ki, Powstanie Okregu Generalnego Wojska Polskiego w Łodzi w 1918 r., [w:] 75-lecie odzyskania niepodległości przez Polskę. Łódź i województwo łódzkie. Materiały z sesji naukowej. Łódź 12 listopada 1993 r., red. K. Badziak i J. Szymczak, Łódź 1993, s. 107; W. J a r n o, Powstanie Okręgu Generalnego Wojska Polskiego nr IV w Łodzi i tworzenie jego struktur lod listopada 1918 r. do sierpnia 1919 r.), [w:] O suwerenność państwowa i narodowa. W 80 rocznice odzyskania niepodległości przez Polskę. Materiały $z$ sesji naukowej. Łódź 10 listopada 1998 r., red. S. Pytlas i H. Siemiński, Łódź 1999, s. 74-75; i d e m, Okręg Korpusu Wojska Polskiego nr IV Łódź 1918-1939, Łódź 2001, s. 19-21. 
trafnie ukazał Włodzimierz Kozłowski: „Tymczasem w kraju rozpoczęło się samorzutne, sukcesywne rozbrajanie wojsk okupacyjnych. Był to proces złożony, który przebiegał nierównomiernie i $z$ różnymi wynikami. Rzecz jasna, sprawy te zależały od wielu czynników. Jednak wbrew utartemu, jednostronnemu obrazowi przełomowych dni, wyzwolenie nie nastapiło łatwo, szybko i bezkrwawo. Tak było na obszarze okupacji austriackiej. Natomiast z Niemcami poszło znacznie trudniej"9. Podobnie sytuacja wygladała w miastach regionu łódzkiego. Oddziały niemieckie dążyły do jak najszybszego powrotu do Niemiec, a strona polska jako warunek bezpiecznego wyjazdu stawiała żądanie oddania broni, na co Niemcy $z$ reguły nie chcieli się zgodzić. W rezultacie dochodziło na tym tle do starć i potyczek.

Tak też stało się m.in. w Tomaszowie Mazowieckim, w którym akcja rozbrajania żołnierzy niemieckich przybrała dramatyczny charakter. Według Włodzimierza Rudzia niemiecka kompania Rybnickiego Batalionu Landszturmu już 11 listopada podjęła przygotowania do wyjazdu $z$ miasta. Żołnierze niemieccy planowali dołączyć rankiem następnego dnia na tutejszej stacji kolejowej do pociagu, którym niemiecki pododdział wojskowy ze Spały (dowódca kpt. Richter, imię nieznane) zamierzał odjechać do Niemiec. Pododdział ten przybył na tomaszowska stację rankiem 12 listopada i po załadowaniu się do wagonów czekał na żołnierzy tomaszowskiej kompanii. Obawiając się wrogich zachowań Polaków, niemiecki oddział chciał przemaszerować $z$ ul. Pilicznej 12 i 14 na dworzec kolejowy w pełnym uzbrojeniu. Na wieść o tym w godzinach porannych (12 listopada) burmistrz Tadeusz Osiński oraz komisarz policji Michał Marafeld (mianowany tego dnia przez burmistrza - komendanta Milicji Robotniczej) zażądali od Niemców złożenia broni, gwarantując w zamian swobodny wyjazd $z$ miasta. W napiętej atmosferze doszło do rozmów, zakończonych zawarciem przed południem umowy zgodnej $z$ oczekiwaniem polskiej strony. Jednak w trakcie składania broni doszło do przypadkowej strzelaniny, po której żołnierze niemieccy zostali odprowadzeni pod eskorta na dworzec kolejowy. Tu doszło do kolejnego napięcia, gdy Polacy zażądali oddania broni przez niemiecki pododdział ze Spały. Po kilku godzinach Niemcy zgodzili się na to, dzięki czemu około godziny 16.00 pociagg odjechał w kierunku Koluszek, a następnie Kalisza. Jeszcze tego samego dnia Polacy zajęli opuszczone kosza-

\footnotetext{
9 W. Ko złow s ki, Powstanie okręgu..., s. 109.
} 
ry przy ul. Pilicznej 12 i 14, gdzie zaczęto organizować pierwsze polskie oddziały wojskowe ${ }^{10}$.

W połowie listopada $1918 \mathrm{r}$. proces formowania polskiej armii miał charakter wielkiej improwizacji, spowodowanej tworzeniem różnych oddziałów - nawet najdrobniejszych - oraz rwącą się praca organizacyjna aparatu terenowego, co przyniosło ograniczone wyniki. Dopiero utworzenie 17 listopada 1918 r. pięciu okręgów generalnych pozwoliło przyspieszyć ten proces. Jednym $z$ nich był OGŁ (mający swa siedzibę w Łodzi) obejmujaccy obszar czterech okręgów wojskowych: VIII - łódzkiego, IX - kaliskiego, X - łowickiego i XI - włocławskiego ${ }^{11}$. Rozwój armii polskiej - w początkowym okresie - został oparty na zaciagu ochotniczym, który tworzył kadry dla powstających oddziałów, złożonych głównie $z$ legionistów, członków POW oraz oficerów $z$ byłych armii państw zaborczych. Dużą rolę w formowaniu oddziałów wojskowych odegrali członkowie POW, którzy organizowali także samodzielnie własne oddziały. W Tomaszowie Mazowieckim to oni stanowili trzon improwizowanego oddziału wojskowego, powstałego w połowie listopada. Miesiąc później został on wcielony do organizowanego w Łodzi - przez dowództwo VIII Okręgu Wojskowego - Okręgowego Pułku Piechoty. Pod koniec listopada $1918 \mathrm{r}$. sformowano w nim dwa pierwsze bataliony. Natomiast III batalion powstał poczatkowo jako batalion POW i do pułku został włączony 15 grudnia. Wszystkie bataliony miały podobna strukturę i miały po cztery kompanie piechoty i jednej kompanii ckm. Mimo trudności pułk - przemianowany w międzyczasie na 28. pp - 28 grudnia 1918 r. liczył już 68 oficerów i podoficerów oraz 2680 szeregowych ${ }^{12}$.

Do pułku stopniowo wcielano oddziały wojskowe formowane na terenie VIII Okręgu Wojskowego, w tym także $z$ powiatu brzezińskiego, gdzie m.in. w drugiej połowie listopada 1918 r. powstał w Tomaszowie Mazowieckim wspomniany oddział POW pod dowództwem plut. R. Tuchowskiego. Oddział ten stacjonował w dawnych koszarach niemieckich przy ul. Pilicznej 12 i 14, gdzie zgłaszali się kolejni tomaszowscy ochotnicy (głównie byli to legioniści13 i człon-

10 W. Ru dí, op. cit., s. 8-13; P. Ło s s ow s ki, Jak Feniks z popiołów. Oswobodzenie ziem polskich spod okupacji w listopadzie 1918, Łowicz 1998, s. 202-203.

11 „Dziennik Rozkazów Ministerstwa Spraw Wojskowych” 1918, nr 6 z 27 XI.

12 W. J a r n o, Okreg Korpusu..., s. 57.

13 Już w październiku 1914 r. zgłosiło się do Legionów kilkunastu tomaszowian, na czele $z$ twórca tomaszowskiego skautingu Janem Jagminem Sadowskim, 
kowie POW). Oddział dość szybko osiagnął liczebność kompanii piechoty, a dowództwo plutonów objęli Jan Goździk i Stanisław Zwojszczyk. W tym samym czasie powstała nieetatowa komenda placu, na czele której staną Stefan Gogolewski, oraz niewielki oddział żandarmerii pod dowództwem Artura Lameckiego. Procesowi tworzenia wojska w Tomaszowie Mazowieckim towarzyszyły jednak liczne problemy natury kadrowej i wyposażeniowej, choć dzięki przejętej od Niemców broni nie było kłopotów $z$ wyposażeniem żołnierzy w broń indywidualną (karabiny). Jednak zasadniczą trudnością była kwestia wyszkolenia ochotników. Choć część $z$ nich ja miała (zdobyta np. w trakcie służby w Legionach Polskich czy na tajnych kursach), to jednak wymogi regularnej armii stawiały $\mathrm{w}$ tym względzie znacznie większe wymagania. Tomaszowski oddział POW funkcjonował poczatkowo samodzielnie, lecz w połowie grudnia 1918 r. został podporządkowany dowództwu 28. pp i wszedł w jego skład jako 3. kompania strzelecka I batalionu. Przez kolejnych kilka tygodni kompania szkoliła się w swych tomaszowskich koszarach, zwiększając swój stan osobowy do około 300 ludzi. Następnie - na rozkaz dowództwa pułku - odeszła 11 stycznia 1919 r. do Łodzi, skąd 15 czerwca $z$ całym I batalionem odjechała do Małopolski Wschodniej. Tam 13 lipca - w ramach procesu formowania 10. Dywizji Piechoty - połaczono 28. pp z 13. Pułkiem Strzelców 4. Dywizji Strzelców gen. ppor. Lucjana Żeligowskiego. W ten sposób powstał 28. pSK, który (z 29., 30. i 31. pSK oraz 10. Pułkiem Artylerii Polowej14 i 10. pac) stanowił trzon 10. Dywizji Piechoty ${ }^{15}$.

Po opuszczeniu Tomaszowa Mazowieckiego przez 3. kompanię 28. pp zlikwidowano istniejąca $\mathrm{w}$ mieście nieetatowa komendę placu. Kontynuowano jednak akcję zaciagowa, która kierował oficer ewidencyjny dla powiatu brzezińskiego (personaliów nie ustalono). Pozyskanych ochotników wysyłano następnie do Łodzi. Tu wcielano ich najpierw do powstałego w maju 1919 r. Batalionu Zapasowego 28. pp, po czym zasilali oni szeregi różnych pododdziałów

ogółem zaś w latach 1914-1916 liczbę ochotników z Tomaszowa Mazowieckiego i jego okolic szacuje się na około 150 osób. Warto tu jeszcze dodać, że wiosna 1915 r. utworzono w mieście punkt werbunkowy mający przyjmować chętnych do służby w powstającej w Piotrkowie Trybunalskim III Brygady Legionów, w wyniku czego część tomaszowskich ochotników trafiła do 4. i 6. pp legionów.

$14 \mathrm{Z}$ dniem 1 I 1932 r. zmienił nazwę na 10. Pułk Artylerii Lekkiej.

15 W. J a r n o, Okreg Korpusu..., s. 57; W. Z a b o r ow s k i, Zarys historii wojennej 28 Pułku Strzelców Kaniowskich, Warszawa 1928, s. 9. 
pułku. Wiosną 1919 r. wprowadzono pobór przymusowy, co zwiększyło zakres zadań służby poborowej. Od listopada 1918 r. Tomaszów Mazowiecki $-z$ powiatem brzezińskim - podlegał pod tym względem PKU dla VIII Okręgu Wojskowego mieszczącej się w Łodzi (komendant płk Henryk Koiszewski). Komenda ta odpowiadała za przeprowadzanie poboru na podległym jej obszarze oraz prowadzenie ewidencji mężczyzn niewcielonych do wojska. Latem 1919 r. - po podporządkowaniu OGE dwóch nowo sformowanych dywizji piechoty - rozkazem z 7 lipca Ministerstwo Spraw Wojskowych zarządziło reorganizację służby poborowej. Od tej pory każdy z ośmiu pułków piechoty podległych organizacyjnie dowództwu OGŁ miał mieć własną komendę uzupełnień odpowiedzialną za napływ uzupełnień. W tym celu dowództwo OGE zreorganizowało 21 sierpnia aparat poborowy na obszarze okręgu. W miejsce dotychczasowych czterech komend utworzono osiem nowych, w tym cztery dla 4. Dywizji Piechoty (PKU 10. pp w Łowiczu, PKU 14. pp we Włocławku, PKU 18. pp w Koninie i PKU 37. pp w Kutnie) oraz cztery dla 10. Dywizji Piechoty (PKU 28. pSK w Łodzi - administrowała w zakresie spraw poborowych częścią Łodzi, PKU 29. pSK w Kaliszu - powiatem kaliskim i sieradzkim, PKU 30. pSK w Brzezinach - powiatem brzezińskim, rawskim i skierniewickim oraz PKU 31. pSK w Łodzi - łaskim, łódzkim oraz częścia miasta Łodzi). Nowa organizacja służby poborowej przetrwała do końca istnienia OGE, tj. do listopada 1921 r. W rezultacie od sierpnia 1919 r. Tomaszów Mazowiecki podlegał w sprawach poborowych PKU 30. pSK w Brzezinach, na czele której pozostał początkowo płk H. Koiszewski. Nie jest to jednak pewne, gdyż część źródeł wskazuje na to, że został nim mjr Mikołaj Koiszewski (sprawa ta wymaga dalszych badań i wyjaśnienia). W sierpniu 1919 r. stanowisko komendanta objął $z$ kolei ppłk Michał Tomasiewicz, a w następnym miesiącu płk Lucjan Ruszczewski ${ }^{16}$.

Wiosna 1919 r. w Brzezinach utworzono Batalion Zapasowy 30. pSK, lecz niebawem dowództwo OGŁ zdecydowało o jego przeniesieniu do znacznie większego Tomaszowa Mazowieckiego, w którym łatwiej było znaleźć odpowiednie budynki dla potrzeb kwaterunku wojskowego. Przesunięcie batalionu odbyło się jeszcze w czerwcu 1919 r., lecz o jego początkowej dyslokacji w Tomaszowie Mazo-

16 Rozkaz tajny oficerski nr 64 z 20 IX 1919 r., Rozkaz dzienny nr 179 z 6 XI 1919 r. i nr 191 z 21 XI 1919 r., CAW, Dziennik Rozkazów OGE; Pismo PKU 30. pSK z 11 II 1920 r., APT, AMTM, sygn. 7/III, teczka 299, nlb. 
wieckim niewiele wiadomo oprócz tego, że 3. kompania została ulokowana w pomieszczeniach Fabryki Sukna i Kortów Karola Bartkego przy dzisiejszej ul. Warszawskiej 2. Miejsce zakwaterowania pozostałych kompanii pozostaje nieznane. Brakuje także wiadomości o dalszym wykorzystywaniu przez wojsko dawnych koszar niemieckich przy ul. Pilicznej 12 i 14, co może sugerować, że pozostałe pododdziały batalionu także ulokowano w jakichś budynkach fabrycznych. Sytuacja ta nie sprzyjała szkoleniu rekrutów, toteż już na przełomie lat 1919 i 1920 władze wojskowe podjęły starania o przydzielenie nowych pomieszczeń mogacych pomieścić cały batalion. Było to tym bardziej pilne, że szybko pojawił się problem w zakwaterowaniu 3. kompanii zajmującej część pomieszczeń w fabryce K. Bartkego, co utrudniało wznowienie w niej produkcji. Jej właściciel kilkukrotnie zwracał się do władz Tomaszowa Mazowieckiego o przydzielenie kompanii innych pomieszczeń. Również dowództwo OGE w piśmie do Magistratu z 17 stycznia 1920 r. poruszało temat przydzielenia tej kompanii nowego lokalu. W odpowiedzi (29 stycznia) Magistrat zaproponował wykorzystanie w tym celu budynków nieczynnej Fabryki Sukna Braci Fürstenwalda i Simona przy ul. Jeziornej 20. Wymagały one jednak niezbędnego remontu i dostosowania ich dla potrzeb kwaterunku wojskowego, przez co zakwaterowanie w nich całego Batalionu Zapasowego 30. pSK nastapiło prawdopodobnie na przełomie 1920 i 1921 r. Dowodził nim początkowo mjr Karol Dziekanowski, a od 25 lipca 1920 r. płk H. Koiszewski (do sierpnia 1919 r. - jak wspomniano komendant PKU 30. pSK) ${ }^{17}$.

Rozkazem z 22 sierpnia 1919 r. wprowadzono jednolita organizację batalionów zapasowych pułków piechoty. Składał się on $z$ dowództwa batalionu, pięciu kompanii zapasowych (trzy strzeleckie, jedna ckm i jedna ozdrowieńców) oraz szkoły podoficerskiej (zazwyczaj przy jednej z kompanii zapasowych). Stałą kadrę tworzyły personel instruktorski oraz obsada administracyjna. Przybywajacych do batalionu poborowych przydzielano najpierw do kompanii zapasowych, przy których tworzono kompanie marszowe wysyłane po kilkutygodniowym (cztery-sześć tygodni) szkoleniu jako uzu-

17 Rozkazy z lat 1919-1921, CAW, Dziennik Rozkazów OGE; Pismo PKU 30. pSK z 11 II 1920 r., pismo dowództwa OGŁ do Magistratu Miasta Tomaszowa z 17 I 1920 r. i pismo Magistratu Miasta Tomaszowa z 29 I 1920 r., APT, AMTM, sygn. 7/III, teczka 299, nlb; Rozkaz dzienny dowództwa Batalionu Zapasowego 30. pSK nr 86 z 6 VIII 1919 r., ibidem, teczka 164, nlb. 
pełnienia na front ${ }^{18}$. Utworzenie PKU 30. pSK i Batalionu Zapasowego 30. pSK spowodowało, że od połowy 1919 r. poborowi $z$ Tomaszowa Mazowieckiego, jak i całego powiatu brzezińskiego zasilali walczący na froncie 30. pSK. Dla przykładu, 2 maja 1920 r. miasto opuściły dwie kompanie marszowe: kompania VI serii licząca 210 ludzi i kompania VII serii licząca 109 ludzi. O obsadzie omawianego batalionu niewiele wiadomo. Jedyne pełniejsze dane pochodza $z$ marca, kiedy na jego czele stał mjr K. Dziekanowski, na stanowisku dowódcy 1. kompanii - por. Stefan Stefanicki, dowódcy 2. kompanii - por. Jan Kożołowski, dowódcy 3. kompanii por. Janusz Szaniecki, a dowódcy kompanii ckm - por. Paweł Dziechowski19.

W styczniu 1920 r. z Brzezin do Tomaszowa Mazowieckiego przeniesiono również PKU 30. pSK. Nie wiązało się to jednak ze zmiana jej nazwy - nadal odpowiadała ona numeracji pułku, który miała zasadniczo uzupełniać, stąd też nadal nosiła nazwę PKU 30. pSK. Komendę ulokowano przy ul. św. Tekli 30 (obecnie ul. Norberta Barlickiego), gdzie swój lokal miała przez kolejnych siedem lat. Omawiana komenda płk L. Ruszczewski kierował od października 1919 r. do 10 grudnia 1920 r., kiedy ze względu na stan zdrowia został odwołany $z$ zajmowanego stanowiska i 1 maja $1921 \mathrm{r}$. przeniesiony w stan spoczynku. Nowym komendantem omawianej komendy został następnie 10 grudnia 1920 r. ppłk Władysław Łokczewski20. Jej przeniesienie do Tomaszowa Mazowieckiego wzmocniło rolę tutejszego garnizonu, czego wyrazem było utworzenie w lutym 1920 r. dowództwa garnizonu (ulokowano je także przy ul. św. Tekli 30) oraz powołanie oficera placu. Dowódca garnizonu - obejmującego powiat brzeziński - został początkowo płk L. Ruszczewski, a od lipca 1920 r. płk H. Koiszewski. W kolejnych miesiacach garnizon powiększony został o pluton żandarmerii 4 . Dywizjonu Żandarmerii, który ulokowano przy ul. św. Antoniego 46.

18 W. J a r n o, Okręg Korpusu..., s. 68-72.

19 Raport stanu Batalionu Zapasowego 30. pSK z 1 III 1920 r., CAW, Generalny Inspektorat Piechoty, sygn. I.300.24, teczka 15, nlb; Dodatek do rozkazu dziennego nr 124 z 5 V 1920 r., ibidem, 30. pSK, sygn. I.320.30, teczka 18, nlb.

20 Po zwolnieniu ze stanowiska komendanta PKU płk L. Ruszczewski mieszkał nadal przy ul. Pilicznej 38 (Wykaz kwater oficerskich w garnizonie tomaszowskim zamieszkałych za czas od 1 sierpnia do 31 sierpnia 1921 r., APT, AMTM, sygn.7/III, teczka 303, nlb) - zmarł 6 października tego roku w Tomaszowie Mazowieckim i tu też został pochowany (Tomaszowski słownik biograficzny, z. 4, red. W. Bogurat, Tomaszów Mazowiecki 2001, s. 28). 
Wiosna 1920 r. garnizonowi podlegały także: Centralna Składnica Amunicji nr 3 pod Spała oraz Dowództwo Dworca Kolejowego i Wojskowa Stacja Wyżywienia w Koluszkach ${ }^{21}$.

Wiosna 1921 r. 10. Dywizja Piechoty powróciła na obszar OGŁ. Jednym $z$ jej oddziałów był 30. pSK skierowany czasowo na postój do Skierniewic (bez II batalionu), ską w myśl pokojowych planów miał zostać przeniesiony na postój stały do Warszawy. Nastapiło to w połowie czerwca. Natomiast II batalion 30. pSK został zakwaterowany w tomaszowskich koszarach przy ul. Jeziornej 20, zajmowanych przez Batalion Zapasowy 30. pSK. Nieco wcześniej, bo w końcu maja został on przeformowany na etat pokojowy i przemianowany na Kadrę Batalionu Zapasowego 30. pSK. Końcowym etapem pokojowej reorganizacji WP było zlikwidowanie 15 listopada 1921 r. okręgów generalnych i utworzenie na ich miejsce dziesięciu okręgów korpusów. Jednym $z$ nich był OK IV, któremu 10. Dywizja Piechoty - $z$ nia także 30. pSK - podlegała aż do 1939 r. Pod względem terytorialnym okręg ten obejmował także powiat brzeziński, a z nim Tomaszów Mazowiecki²2.

Przybycie II batalionu 30. pSK na postój stały do Tomaszowa Mazowieckiego pogorszyło warunki zakwaterowania w budynku pofabrycznym przy ul. Jeziornej 20. Dlatego też latem $1921 \mathrm{r}$. Kadrę Batalionu Zapasowego 30. pSK przeniesiono do budynku przy ul. Pilicznej 38, gdzie stacjonowała do czasu likwidacji w lutym 1924 r. $Z$ innych zmian trzeba tu jeszcze wspomnieć o zredukowaniu plutonu żandarmerii do szczebla posterunku oraz zmianie nazwy PKU 30. pSK na PKU Brzeziny z siedziba w Tomaszowie. Jej komendantem - po przejściu armii na organizację pokojowa - pozostawał do 15 maja 1922 r. ppłk W. Łokczewski, po czym stanowisko to obją ppłk Mikołaj Pełczyński. Stacjonujący w mieście II batalion 30. pSK składał się latem 1921 r. z czterech kompanii strzeleckich oraz jednej kompanii ckm i broni towarzyszacych (etatowo miał liczyć 25 oficerów, 99 podoficerów i 794 szeregowych) ${ }^{23}$. Po przejściu armii na stopę pokojowa tworzyły go w latach 19211924: dowództwo batalionu, trzy kompanie strzeleckie oraz kom-

21 Rozkaz oficerski nr 15 z 22 II 1920 r., CAW, Dziennik Rozkazów OGE; Wykaz garnizonów w OGŁ $z 1$ III 1921 r., ibidem, OK II, sygn. I.371.2, teczka 1, nlb.

22 Rozkazy dowództwa 10. Dywizji Piechoty z końca 1921 r., CAW, 10. Dywizja Piechoty, sygn. I.313.10, teczka 3; W. J a r n o, Okreg Korpusu..., s. 85-89; P. Z a r z y c k i, 4 Pułk Artylerii Ciężkiej, Pruszków 1999, s. 9.

23 W. Jarno, Strzelcy Kaniowscy $w$ latach 1919-1939, Warszawa 2004, s. $139-144$. 
pania ckm i broni towarzyszących. Jego dowódca w latach 19211924 był mjr Tadeusz Podwysocki, a dowódca Kadry Batalionu Zapasowego 30. pSK kpt. Stanisław Parkasiewicz (następnie po awansie na stopień majora objał dowództwo III batalionu 30 pSK) ${ }^{24}$.

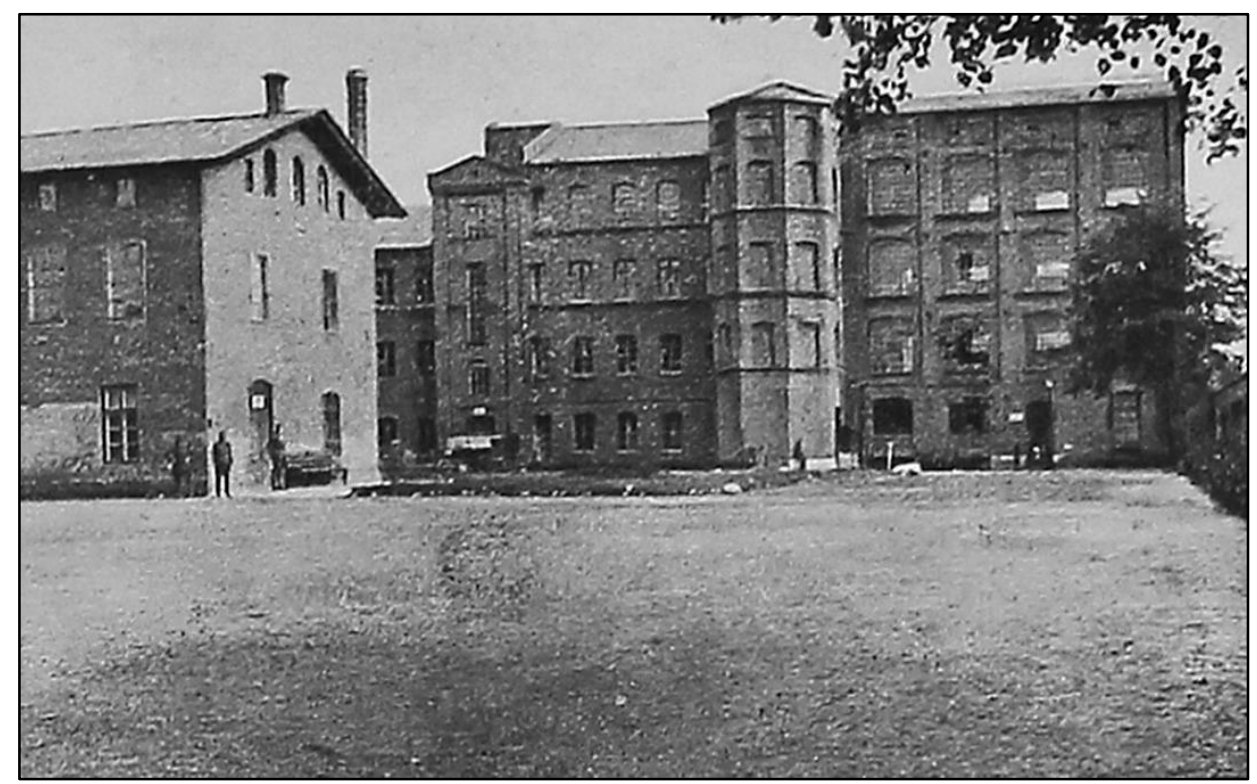

1. Widok koszar przy ul. Jeziornej $20 \mathrm{w}$ Tomaszowie Mazowieckim z $1928 \mathrm{r}$.

Ź r ód ło: Podchorażówka. Baon Podchorażych Rezerwy Piechoty numer 4, Tomaszów Mazowiecki 1928/1929, s. 11.

Warunki zakwaterowania wojska w garnizonie tomaszowskim nie były dobre, toteż w 1922 r. władze garnizonu oraz Szefostwo Inżynierii i Saperów dowództwa OK IV podjęły rozmowy $z$ władzami Tomaszowa Mazowieckiego w sprawie nieodpłatnego przekazania terenów pod budowę nowych koszar. W ich wyniku władze miasta zobowiązały się przekazać kilka działek na ten cel, a władze wojskowe planowany rozpoczać prace budowlane w 1923 r. $25 \mathrm{Na}$ początku 1923 r. wymiana korespondencji między władzami miasta a władzami wojskowymi nabrała przyspieszenia, lecz sporna kwestia pozostało przekazanie pod budowę koszar kilkunastu placów

24 Rocznik Oficerski 1923, Warszawa 1923, s. 212; Rocznik Oficerski 1924, Warszawa 1924, s. 197; W. J a r n o, Okreg Korpusu..., s. 148-149.

25 Pismo zastępcy szefa Inżynierii i Saperów OK IV do Magistratu Miasta Tomaszowa z 13 X 1922 r., APT, AMTM, teczka 472, nlb. 
graniczacych $z$ gazownia miejska. Dnia 18 maja 1923 r. zastępca dowódcy OK IV gen. bryg. Leon Pachucki w piśmie do Magistratu Miasta Tomaszowa przesłał oświadczenie: „Do dnia 1 stycznia 1925 r. opróżnione zostaną pomieszczenia, zajmowane obecnie przez 30 p.S.K. i przez Komendę CSA Nr. 3 w Tomaszowie przy ul. Jeziorowej Nr. 20, Pilicznej Nr. 34, Gustownej Nr. 68, Kolejowej Nr. 38 i Spalskiej Nr. 4 pod warunkiem, że Magistrat Miasta Tomaszowa Mazowieckiego daruje wojskowości pod budowę koszar dla oddziałów stacjonujących w Tomaszowie Mazowieckim plac, opisany $\mathrm{w}$ protokole Komisji Wojskowo-Magistrackiej $z$ dnia 4 kwietnia 1923 r., graniczący na wschód $z$ ulicą Farna [obecnie Legionów - W.J.] i Gazownia Miejska, na północ $z$ gruntami miejskimi oznaczonymi na planie sytuacyjnym liczbami 1, 2 i 3, na wschód $z$ ulica Podleśna i na południe $z$ projektowanym przedłużeniem ulicy Tkackiej, składający się $z$ poszczególnych parcel oznaczonych na planie sytuacyjnym kolejnymi liczbami 4, 5, 6, 7, 8, 9, 10, 11, 12, 13, 14 i 15 [...]. Sporządzenie aktu darowizny nie może przekroczyć terminu 1 lipca 1923 r. w przeciwnym bowiem razie, termin opróżnienia pomieszczeń zajmowanych przez wyżej wymienione oddziały nie mógłby ulec opóźnieniu"26. W odpowiedzi Magistrat zaproponował kilka innych placów położonych w pobliżu, na co ostatecznie władze wojskowe się zgodziły27. Trudno jednak stwierdzić, dlaczego zaplanowanej budowy koszar nie rozpoczęto. Być może jakiś wpływ na to miał zaostrzający się w tym czasie kryzys gospodarczy w kraju i polityka oszczędnościowa powstałego 19 grudnia 1923 r. rządu Władysława Grabskiego. Sa to jednak tylko przypuszczenia, gdyż brak dokumentów w tej sprawie nie pozwala jednoznacznie wyjaśnić tej kwestii.

Jesienia 1923 r. żołnierzami tomaszowskiego batalionu wstrząsnęła wieść o zamachu dokonanym 13 października, gdy wyleciały $\mathrm{w}$ powietrze Centralne Składy Amunicyjne nr 1 mieszczace się w warszawskiej cytadeli, gdzie stacjonowały główne siły 30. pSK. Śmierć poniosło 28 osób, kilkaset zaś zostało rannych. Choć wśród zabitych nie było żołnierzy z 30. pSK, jednak pod gruzami zawalonego bloku mieszkalnego zginęły małżonki trzech podoficerów tego pułku oraz dwójka dzieci. W toku śledztwa ustalono, że

26 Pismo gen. bryg. Leona Pachuckiego do Magistratu Miasta Tomaszowa $z 18$ V 1923 r., APT, AMTM, sygn. 7/III, teczka 472, nlb.

27 Pismo Magistratu Miasta Tomaszowa do dowództwa OK IV z 26 V 1923 r., APT, AMTM, sygn. 7/III, teczka 472, nlb. 
sprawcami zamachu byli prawdopodobnie członkowie Komunistycznej Partii Robotniczej Polski, a za inspiratorów tego zamachu uznano przebywajacych od sierpnia 1923 r. w więzieniu dwóch oficerów: por. Walerego Bagińskiego i ppor. Antoniego Wieczorkiewicza, których 10 grudnia tego roku skazano na karę śmierci28. Na wieść o tragedii 24 października zrodziła się w Tomaszowie Mazowieckim inicjatywa utworzenia Komitetu Niesienia Pomocy Ofiarom Wybuchu w Cytadeli, o czym poinformowano mieszkańców miasta w specjalnej ulotce: „Pragnąc zaś przyjść z pomoca ofiarom katastrofy, wzywamy Obywateli, by pospieszyli z doraźna pomoca, jak to już uczyniła Warszawa i Łódź. W tym celu prosimy o liczne zgromadzenie się w magistracie w dniu $27 / \mathrm{X}$ b.m. o godzinie 6 wieczorem dla zorganizowania komitetu pomocy ofiarom katastrofy"29. Apel ten spotkał się z szerokim oddźwiękiem mieszkańców, dzięki czemu na owym zebraniu powołano komitet, który działał przez kilka kolejnych tygodni 30 .

W połowie 1924 r. władze wojskowe zdecydowały o skupieniu całego 30. pSK w jednym garnizonie. Przygotowania do tego trwały kilka miesięcy i ostatecznie w połowie listopada 1924 r. stacjonujacy w Tomaszowie Mazowieckim II batalion 30. pSK został przeniesiony do Warszawy (Cytadela), gdzie dołaczył do reszty pułku. Nie zakończyło to jednak dziejów tomaszowskiego garnizonu, gdyż prawdopodobnie jeszcze $\mathrm{w}$ grudniu tego roku opuszczone przez niego koszary przy ul. Jeziornej 20 zają II batalion 25. pp ${ }^{31}$. Pułk ten powstał na przełomie listopada i grudnia 1918 r., po czym w składzie 7. Dywizji Piechoty brał udział w wojnie polsko-bolszewickiej. Pod koniec kwietnia 1921 r. pułk z dywizja powrócił

28 A. Ż a k, W 70 rocznice komunistycznej dywersji. Eksplozja w cytadeli, „Polska Zbrojna" 1993, nr 41, s. 1. Wyroku na obu oficerach nie wykonano, gdyż ambasada radziecka zwróciła się do władz polskich o umieszczenie skazanych na liście osób przeznaczonych do wymiany, na co stron polska wyraziła zgodę. Jednak w drodze ku granicy obaj aresztowani zostali zastrzeleni przez polskiego policjanta.

29 Apel do mieszkańców Tomaszowa z 24 X 1923 r., APT, AMTM, sygn. 7/III, teczka 598, nlb.

30 Pismo Komitetu Pomocy Ofiarom Wybuchu w Cytadeli z 28 X 1923 r., APT, AMTM, sygn. 7/III, teczka 598, nlb.

31 Rozkaz nr 92 z 20 IX 1924 r. i Rozkaz tajny nr 47 z 21 XI 1924 r., CAW, Dziennik Rozkazów OK IV; K. W i ą c z e k, W. M a ku le c, Dzieje 25 Pułku Piechoty $w$ latach 1918-1939, Piotrków Trybunalski 1991, s. 15. Natomiast W. M a k u le c (25 Pukk Piechoty, Pruszków 1995, s. 14-15) nie wspomina o stacjonowaniu II batalionu 25. pp w Tomaszowie Mazowieckim. 
na obszar Okręgu Generalnego Kielce. Jesienia tego roku - w ramach pokojowej reorganizacji armii -7 . Dywizja Piechoty została podporządkowana powstałemu 15 listopada dowództwu OK IV, a 25. pp przeniesiono 15 października do Piotrkowa Trybunalskiego ${ }^{32}$.

Ze zmiana dyslokacji II batalionu 25. pp i jego przybyciem do Tomaszowa Mazowieckiego jego dowództwo obją mjr T. Podwysocki, dotychczasowy dowódca II batalionu 30. pSK. Oficer ten cieszył się dobrą opinią wśród przełożonych, czego wyrazem była następująca opinia $z 1928$ r.: "Co do dowódców baonów tej dywizji [tj. 7. Dywizji Piechoty - W.J.], którzy sa mniej więcej jednakiej miary, wyróżniam dowódcę baonu 25. p.p. mjr. Podwysockiego Tadeusza, który odznacza się swoim dużo większym przygotowaniem taktycznym, instruktorskim i administracyjnym (dowódca baonu detaszowanego)"33.

W dniach zamachu majowego stacjonujacy w Tomaszowie Mazowieckim II batalion 25. pp noca $z 13$ na 14 maja 1926 r. ze swym dowódca mjr. T. Podwysockim opowiedział się po stronie zbuntowanych oddziałów popierających akcję podjęta $\mathrm{w}$ stolicy przez Józefa Piłsudskiego. Niestety, nic więcej nie wiadomo o sytuacji w Tomaszowie Mazowieckim w tych dniach, ale można przypuszczać, że żołnierze batalionu obsadzili dworzec kolejowy, kontrolując w ten sposób ważną linię kolejową Koluszki-Skarżysko Kamienna ${ }^{34}$.

Początek następnego roku (tj. 1927) przyniósł likwidację PKU Brzeziny $z$ siedziba $w$ Tomaszowie, co nastapiło 1 stycznia. Od tej pory powiat brzeziński w zakresie służby poborowej podlegał PKU Łódź-Powiat (administrującej także powiatem lódzkim) ${ }^{35}$. Dotychczasowy komendant PKU Brzeziny $z$ siedziba w Tomaszowie Mazowieckim ppłk. M. Pełczyński objął niebawem stanowisko komendanta PKU Końskie, które zajmował do listopada 1928 r. W końcu grudnia 1927 r. dokonano $z$ kolei nowego podziału obszaru OK IV na garnizony wojskowe, zgodnie $z$ którym garnizon tomaszowski obejmował odtąd swym działaniem dwa powiaty: brzeziński (wcho-

32 Szerzej: W. J a r n o, Okregg Generalny Wojska Polskiego nr III Kielce $w$ latach 1918-1921, Łódź 2003, s. 82-88 i 185-187; W. J u s z ki e wi c z, Zarys historii wojennej 25 Putku Piechoty, Warszawa 1928, s. 3-35.

33 Instytut Józefa Piłsudskiego w Ameryce, Archiwum Józefa Piłsudskiego, t. 701.1.118, Opinia generała Osińskiego z 1928 r., k. 265.

34 Szerzej: W. J a r n o, Okreg Korpusu..., s. 291-300.

35 Rozkaz tajny nr 2 z 20 I 1927 r., CAW, Dziennik Rozkazów OK IV. 
dzący w skład województwa łódzkiego) i rawski (należący do województwa warszawskiego).

Dwa miesiące wcześniej dowództwo OK IV - rozkazem z 25 października 1927 r. - nakazało przemianować stacjonujący w Tomaszowie II batalion 25. pp na Szkołę Podchorążych Rezerwy Piechoty nr 4, której pierwszym dowódca został dotychczasowy dowódca wspomnianego batalionu mjr T. Podwysocki. Objął on także stanowisko dowódcy garnizonu (1 stycznia 1928 r. został awansowany do stopnia podpułkownika). Przeformowanie II batalionu 25 . pp miało nastapić niemal natychmiast, gdyż już 26 października miał się on formalnie stać Szkoła Podchorążych Rezerwy Piechoty nr 4 i rozpoczać swa działalność. Szkoła ta pod względem wyszkolenia i prac mobilizacyjnych podlegała dowódcy 25. pp na podobnych zasadach jak pozostałe dwa bataliony pułku. O procesie przeformowania batalionu nic nie wiadomo, ale zapewne musiały mu towarzyszyć poważne zmiany kadrowe, wynikające ze zmiany charakteru owej jednostki ${ }^{36}$.

Szkoła Podchorażych Rezerwy Piechoty nr 4 miała kształcić kandydatów na oficerów rezerwy spośród poborowych $z$ cenzusem $^{37}$, a szkolenie - podobnie jak w innych tego typu szkołach trwało sześć miesięcy i kończyło się egzaminem oraz nadaniem stopnia kaprala lub plutonowego podchorążego, po czym żołnierze ci trafiali jako podchorązowie rezerwy na sześć miesięcy praktyki dowódczej do jednostek liniowych (stopień oficerski otrzymywali po odbyciu dodatkowych ćwiczeń). Dawne budynku fabryczne przy ul. Jeziornej 20 należało ponownie wyremontować, by dostosować je do nowych zadań: „Mieszczą się w murach starej fabryki sukna, w murach ociekajacych jeszcze smarami i oliwa, gdzie $z$ każdego kąta uderzał widok resztek urządzeń fabrycznych, szkoła nie sprawiała zgoła wrażenia wojskowych koszar i nie zapewniała elewom minimum wygód. Brak najprymitywniejszych urządzeń higie-

36 Rozkaz o zorganizowaniu Szkoły Podchorażych Rezerwy Piechoty nr 4 w Tomaszowie Maz. z 25 X 1927 r., CAW, Departament Dowodzenia Ogólnego, sygn. I.300.22, teczka 66, nlb.

37 W 1927 r. mogli się jeszcze w niej uczyć elewi z sześcioklasowym wykształceniem, lecz w 1928 r. zmieniono przypisy i elewami szkoły mogli być elewi z cenzusem, tzn. mający ukończoną szkołę średnią. Dlatego też jedynie część elewów pierwszego kursu opuściła szkołę jako podchorążowie rezerwy, a ci mający ukończona jedynie sześcioklasową szkołę powszechną musieli swą naukę w tej szkole przerwać. 


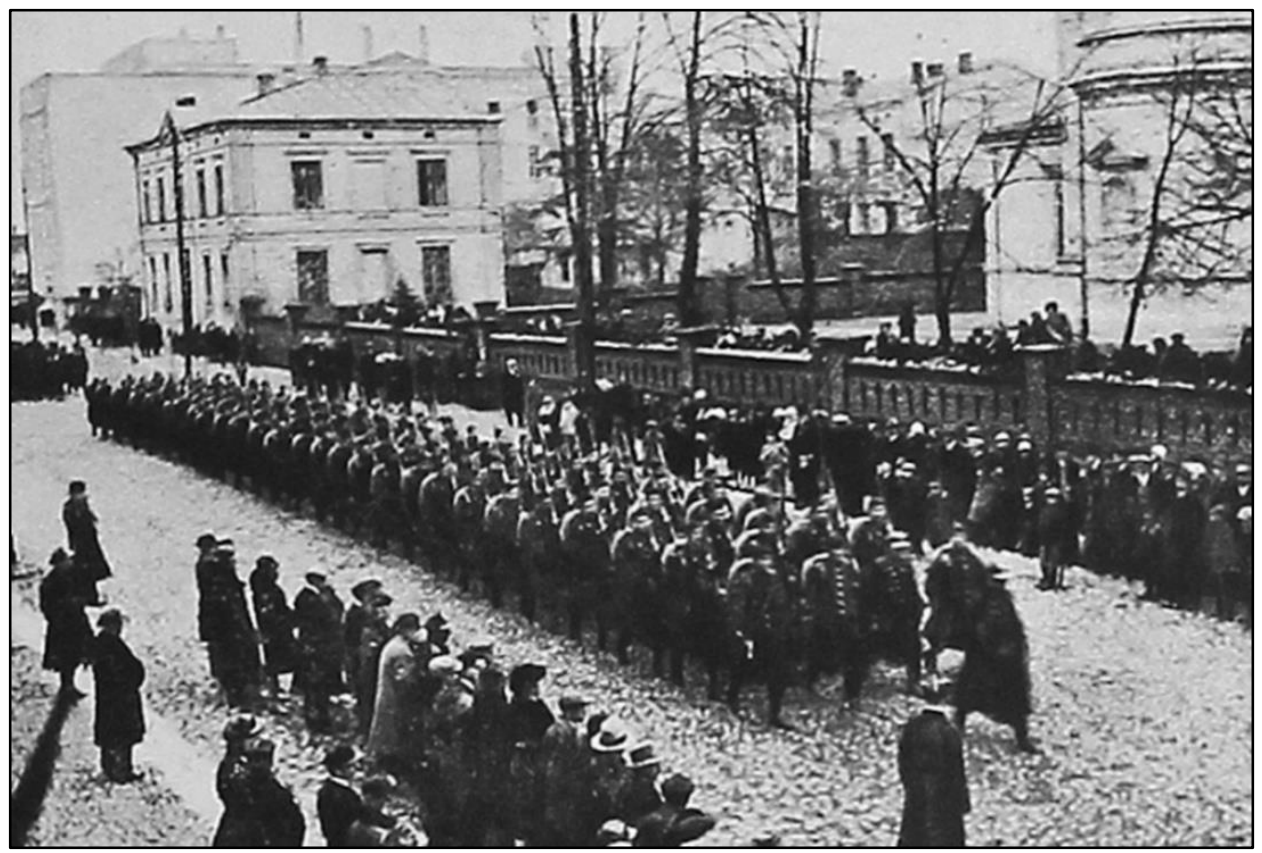

2. Defilada Batalionu Podchorażych Rezerwy Piechoty nr 4 ulica POW w Tomaszowie Mazowieckim latem 1928 r.

Źr ód ło: Podchorażówka. Baon Podchorażych Rezerwy Piechoty numer 4, Tomaszów Mazowiecki 1928/1929, s. 11.

nicznych dawał się dotkliwie we znaki. W takich to niegościnnych murach zaczęli swa pracę pełni zapału i chęci pierwsi elewi"38.

Pierwszy kurs rozpoczał się w szkole 2 listopada 1927 r., a jego zakończeniu nadano 21 kwietnia 1928 r. niezwykle uroczysta oprawę (wśród zaproszonych gości był m.in. ks. biskup polowy Wojska Polskiego Stanisław Gall). W szkole niebawem, 14 maja, rozpoczą się sześciotygodniowy kurs przeszkalajaccy dla podporuczników rezerwy, po którym 17 lipca rozpoczęto zajęcia nowego kursu dla kandydatów na oficerów rezerwy. Ponieważ tomaszowski garnizon nie miał odpowiednich warunków do prowadzenia ćwiczeń terenowych, toteż ostatni miesiąc nauki w szkole elewi spędzali w Obozie Ćwiczeń OK IV w Raduczu pod Skierniewicami ${ }^{39}$. „W szkole realizowany był program przygotowujący podchorażych do dowodzenia plutonem piechoty $z$ tym, że w pierwszym okresie

38 Podchorażówka. Baon Podchorażych Rezerwy Piechoty numer 4, Tomaszów Mazowiecki 1928/1929, s. 26.

39 Ibidem, s. 26-28. 


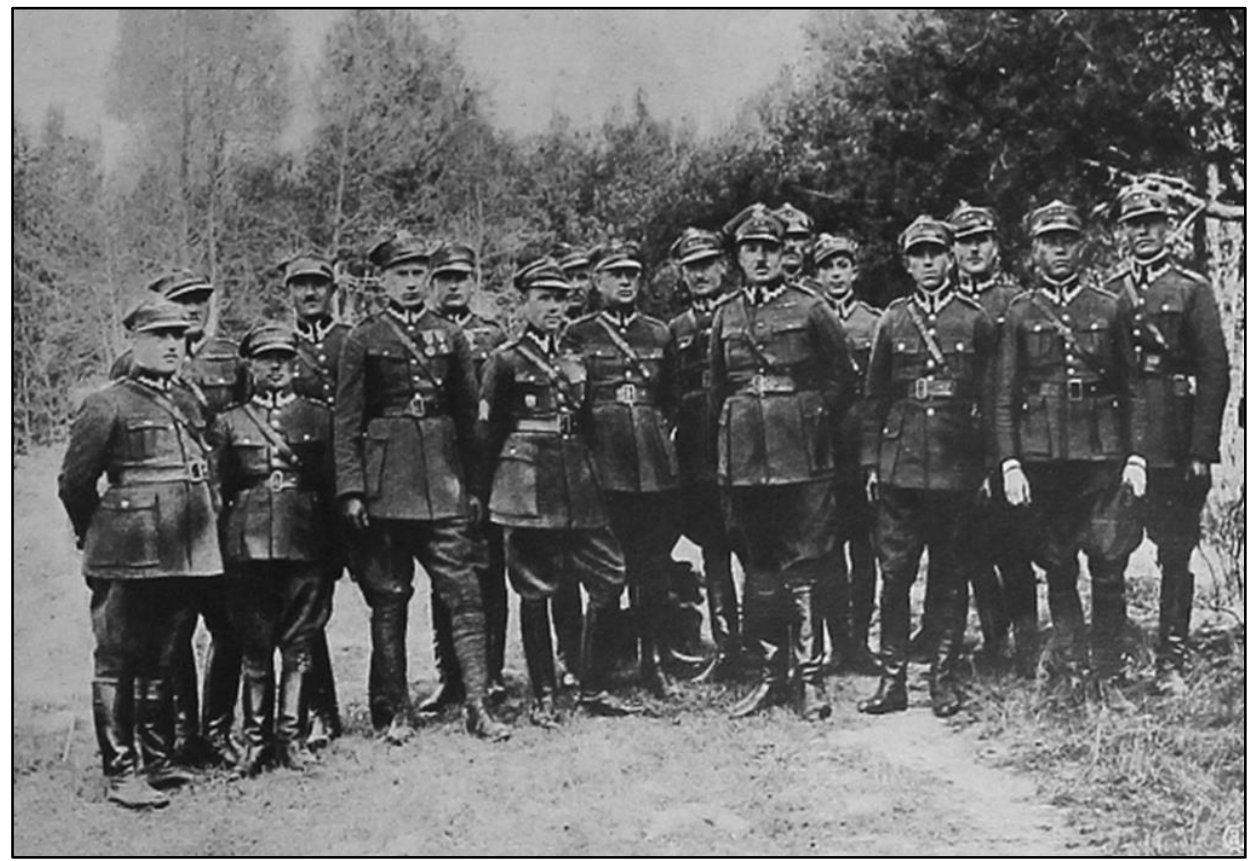

3. Kadra oficerska Batalionu Podchorażych Rezerwy Piechoty nr 4, druga połowa 1928 r.; siódmy z prawej stoi jej dowódca - ppłk Stanisław Dąbek Ź r ó d ło: Podchorażówka. Baon Podchorażych Rezerwy Piechoty numer 4, Tomaszów Mazowiecki 1928/1929, s. 23.

szkolenia kładziono największy nacisk na praktyczne przygotowanie do dowodzenia drużyna piechoty i działonem artylerii. Dominowały zajęcia praktyczne zmierzające do opanowania przez podchorążych sprzętu bojowego. W krótkim czasie starano się nauczyć budowy i obsługi podstawowych rodzajów broni strzeleckiej, granatów, lekkiego moździerza piechoty "granatnika ID" i działka $75 \mathrm{~mm}$. $Z$ ogólnych zajęć teoretycznych wykładano jedynie historię Polski i geografię" 40 .

Na początku sierpnia 1928 r. Szkołę Podchorażych Piechoty nr 4 przemianowano na Batalion Podchorążych Rezerwy Piechoty nr 4, którego dowództwo 6 sierpnia objął ppłk Stanisław Dąbek, a stanowisko zastępcy dowódcy mjr Antoni Sikorski. Dokonano wówczas także zmian na stanowiskach dowódców kompanii. Ich obsada do czasu likwidacji batalionu wyglądała następująco: dowódca

40 http://tptm.eu/index.php?option=com_content\&view=category\&layout=blog \&id=84\&Itemid=489 (dostęp: 25 II 2015 r.). 
1. kompanii - kpt. Michał Kosterkiewicz, 2. kompanii - kpt. Kazimierz Zdanowicz, 3. kompanii - kpt. Józef Drelichowski i 4. kompanii - kpt. Stanisław Rink.

Batalion istniał jednak bardzo krótko, gdyż wobec utworzenia w maju 1929 r. Szkoły Podchorażych Rezerwy Piechoty w Zambrowie władze wojskowe zdecydowały o przeniesieniu do tej szkoły całego dotychczasowego personelu Batalionu Podchorażych Rezerwy Piechoty $\mathrm{nr}$ 4. W rozkazie Ministra Spraw Wojskowych z 6 czerwca czytamy: „Zarządzam utworzenie ośrodka szkolnego dla podchorążych rezerwy piechoty $w$ Zambrowie i w tym celu przenoszę bataliony podchorażych rezerwy piechoty $\mathrm{nr} 4 \mathrm{z}$ Tomaszowa Maz., nr 6 z Zaleszczyk i nr 9A z Łukowa oraz przeorganizowuję je na Szkołę Podchorążych Rezerwy Piechoty"41. Ponieważ w tym czasie w Batalionie Podchorażych Rezerwy Piechoty nr 4 odbywał się trwający od 3 czerwca do 14 lipca kurs, toteż ostateczne rozwiązanie batalionu nastapiło 22 lipca. W tej sytuacji dalsze istnienie garnizonu straciło sens i w połowie lipca 1929 r. rozpoczęto jego likwidację, zwalniając $z$ kwaterunku wojskowego nieruchomości przy ul. Jeziornej 20 (koszary), lokalu przy ul. Pilicznej 6 (kasyno oficerskie) i placu Steinbacha w Tomaszowie Mazowieckim (ul. św. Antoniego 48, położona po sąsiedzku $z$ posesja pod numerem 46, gdzie mieścił się posterunek żandarmerii). Niebawem także i ten posterunek został zlikwidowany. Lipiec 1929 r. przyniósł więc usunięcie tomaszowskiego garnizonu, a wojsko znikło $z$ jego ulic na sześć lat.

Kolejny etap w wojskowych dziejach Tomaszowa Mazowieckiego otworzył rok 1935, gdy z Częstochowy na postój stały przybył II dywizjon 4. pac. Pułk ten powstał jesienia 1921 r. Rozlokowano go wówczas w Łodzi (dowództwo pułku z I dywizjonem i Kadrą Baterii Zapasowej) oraz Częstochowie (II dywizjon) ${ }^{42}$. W drugiej połowie 1924 r. rozformowano Kadrę Baterii Zapasowej, a rok później rozkazem z 27 listopada 1925 r. - sformowano w Lodzi III dywizjon. Trzy lata później dokonano kolejnej reorganizacji, w wyniku której do wybuchu II wojny światowej każdy $z$ jego dywizjonów liczył po dwie baterie. Ostatnia poważna reorganizacja nastąpiła

41 Rozkaz o przeniesieniu Batalionów Podchorażych Rezerwy Piechoty nr 4, 6 i 9A do Zambrowa z 6 VI 1929 r., CAW, Biuro Personalne, sygn. I.300.18, teczka 48, nlb.

42 W. J a r n o, Okreg Korpusu..., s. 111-112; K. G a ls t e r, Ksiega pamiatkowa artylerii polskiej 1914-1939, Londyn 1975, s. 102-103; P. Z a r z y c k i, op. cit., s. 9; R. Ło ś, Artyleria polska 1914-1939, Warszawa 1991, s. 51-53. 
w styczniu 1930 r., gdy ujednolicono uzbrojenie baterii. Odtad I i II dywizjon 4. pac liczył po dwie baterie haubic $155 \mathrm{~mm}$ wz. 17, a III dywizjon - dwie baterie armat $105 \mathrm{~mm}$ wz. 13 (potem wz. 29). W 1932 r. wprowadzono także nowy pokojowy etat pułku, w myś1 którego miał liczyć 42 oficerów, 783 szeregowych i 341 koni ${ }^{43}$.

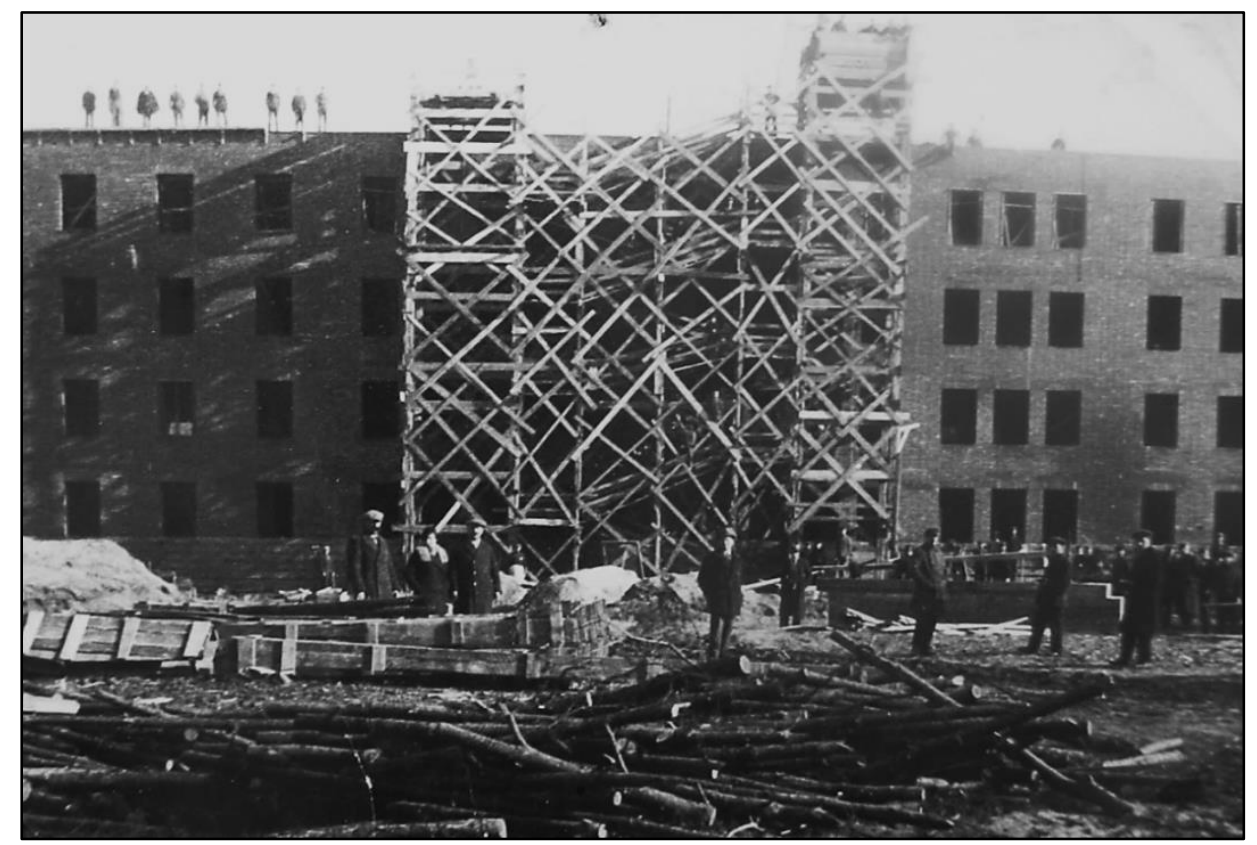

4. Budowa koszar dla II dywizjonu 4. pac w Tomaszowie Mazowieckim, wiosna 1935 r. (ze zbiorów Krzysztofa Zakrzewskiego)

Przeniesienie II dywizjonu 4. pac do nowych koszar w Tomaszowie Mazowieckim było spowodowane $z$ jednej strony złymi warunkami zakwaterowania dywizjonu w Częstochowie (dzielił tam koszary $z$ 7. Pułkiem Artylerii Lekkiej), $z$ drugiej - zamiarem skoncentrowania $\mathrm{w}$ niedalekiej przyszłości całego 4. pac w jednym garnizonie. Ponieważ na obszarze OK IV nie było wolnych koszar nadających się na potrzeby artylerii ciężkiej, toteż ostatecznie $\mathrm{w}$ ramach opracowanego na początku lat trzydziestych planu mo-

43 Rozkaz wykonawczy o wprowadzeniu w życie nowej organizacji artylerii na stopie pokojowej z 10 V 1924 r., CAW, Departament Artylerii, sygn. I.300.34, teczka 6, nlb; Rozkazy dowództwa 4. pac z 1925 r., ibidem, 4. pac, sygn. I.322.51, teczka 8, nlb; W. J a r n o, Okregg Korpusu..., s. 152-155. 
dernizacji armii - władze wojskowe zdecydowały wybudować dla owego dywizjonu nowe koszary. Miały one w pełni odpowiadać stawianym tego rodzaju broni wymaganiom, zwłaszcza w zakresie działowni, stajni, składów amunicyjnych i magazynów oraz wyposażenia koszar, dostosowanych do wymogów obrony przeciwlotniczej. Koszary te wybudowano - kosztem 1,7 mln złotych - w zachodniej części miasta w latach 1934-1935. Z uwagi na wybuch II wojny nie zdążono ich rozbudować, toteż dowództwo 4. pac z I i III dywizjonem do mobilizacji stacjonowały w Łodzi. Po ukończeniu budowy koszar dla II dywizjonu Departament Dowodzenia Ogólnego 18 września 1935 r. zdecydował o zmianie jego dyslokacji i przeniesieniu $z$ Częstochowy do Tomaszowa Mazowieckiego, a 30 września zarządził niezwłoczne przeprowadzenie owej translokacji. Tego dnia dowództwo II dywizjonu wydało ostatni rozkaz w Częstochowie 44 .

Władze lokalne były w oczywisty sposób zainteresowane stacjonowaniem na swoim terenie jednostki wojskowej, co znaczaco wpływało na jego rozwój gospodarczy. Niezależnie od dostaw broni i amunicji armia stale potrzebowała wielu innych produktów, jak np. umundurowania i oporządzenia, żywności, koni i zwierząt pociagowych czy też materiałów budowlanych. Wszystkie te - zasygnalizowane w zarysie - potrzeby stwarzały handlowi, przemysłowi, rzemiosłu i rolnictwu ogromna szansę zbytu swoich produktów, a dzięki temu wpływały na zmniejszenie panującego bezrobocia. Dlatego też odtworzenie garnizonu w Tomaszowie Mazowieckim było dla władz miasta, jak i jego mieszkańców ważne nie tylko ze względów ekonomicznych, lecz także prestiżowych. Nic więc dziwnego, że II dywizjon 4. pac postanowiono uroczyście powitać, nadając dużą rangę temu wydarzeniu. Już w połowie października 1935 r. - pod przewodnictwem prezydenta miasta Antoniego Raczaszka - powołano Obywatelski Komitet Przyjęcia Dywizjonu 4. pac, który zaplanował oficjalna uroczystość powitania dywizjonu na 10 listopada. W jej przededniu komitet wystosowal do tomaszowian specjalną odezwę: „W niedziele dnia 10 listopada b.r. odbędzie się w naszym mieście uroczyste powitanie II Dywizjonu 4 Pułku Artylerii Ciężkiej przybywającego do Tomaszowa na stały

44 Rozkazy o translokacji wojsk na obszarze OK IV z 18 i 30 IX 1935 r., CAW, Departament Artylerii, sygn. I.300.34, teczka 14, nlb; Rozkaz dowództwa II dywizjonu 4. pac nr 215 z 30 IX 1935 r., ibidem, 4. pac, sygn. I.322.51, teczka 39, nlb; W. J a r n o, Okreg Korpusu..., s. 146; P. Z a r z y cki, op. cit., s. 11. 
pobyt. Całe społeczeństwo naszego miasta $z$ najgorętszą radościa wita Dywizjon, jako przedstawiciela naszej zwycięskiej Armii, która pod wodza Wielkiego Marszałka wyrąbała Polsce granice, a dziś stoi niestrudzenie na straży naszej niepodległości. Aby dać wyraz uczuciom przywiązania, podziwu i wdzięczności dla naszej Armii, Komitet wzywa Organizacje b. wojskowych, Cechy, wszelkie Stowarzyszenia, Związki i Instytucje do wzięcia udziału z pocztami sztandarowymi w powitaniu przybywajacego wojska. Komitet wzywa też wszystkich mieszkańców miasta, aby stawili się tłumnie w dniu 10 listopada na Rynku Kościuszki i trasie przemarszu wojska, aby udekorowali domy i sklepy barwami narodowymi i barwami pułku, zaś cała postawa zamanifestowali, iż dzień powitania wojska jest dla miasta naszego prawdziwym świętem" 45 .

W celu podkreślenia wagi tej uroczystości zaproszono na nia kilkudziesięciu gości, w tym m.in. spośród przedstawicieli władz cywilnych: Aleksandra Hauke-Nowaka (wojewodę łódzkiego), Antoniego Potockiego (wicewojewodę), Tadeusza Reinda (starostę brzezińskiego), Józefa Torwińskiego (komendanta wojewódzkiego Policji Państwowej z Łodzi) oraz posłów na Sejm - Stanisława Pomianowskiego i Jana Drozda-Gierymskiego. Nie mniej godnie wyglądało grono zaproszonych wojskowych, wśród których znaleźli się m.in. gen. bryg. Władysław Langner (dowódca OK IV), płk Leonard Lubański (dowódca 4. Grupy Artylerii), płk dypl. Tadeusz Alf-Tarczyński (szef sztabu dowództwa OK IV), płk Leon Bogusławski (dowódca 4. pac), płk Leopold Toruń (szef Departamentu Budownictwa), ppłk Stanisław Burnagel (szef Intendentury OK IV) i mjr Stanisław Więckowski (szef Budownictwa OK IV). Oczywiście najważniejsi byli żołnierze II dywizjonu 4. pac, a wśród nich m.in. mjr Rudolf Ostrihansky (dowódca dywizjonu), kpt. Hipolit Burchard (kwatermistrz dywizjonu), kpt. Józef Kopacz (dowódca 4. baterii) i kpt. Władysław Car (dowódca 5 . baterii) ${ }^{46}$.

Uroczystość odbyła się - tak jak zaplanowano - 10 listopada 1935 r. W południe na placu Tadeusza Kościuszki zgromadziły się

45 Odezwa Antoniego Rączaszka przewodniczącego Obywatelski Komitet Przyjęcia Dywizjonu 4. pac z początku listopada 1935 r., APT, Zbiór akt różnych, sygn. 277 , teczka 10 , nlb.

46 Lista zaproszonych gości na uroczystość powitania II dywizjonu 4. pac w Tomaszowie Maz. w dniu 10 XI 1035 r., APT, Zbiór akt różnych, sygn. 277, teczka 10, nlb; Rozkazy dowództwa 4. pac z 1935 r., CAW, 4. pac, sygn. I.322.51, teczka 24. 
władze miasta, zaproszeni goście oraz delegacje lokalnych organizacji, stowarzyszeń, cechów i szkół. Około 12.45 odbyła się właściwa ceremonia powitania dywizjonu, zakończona defilada, po której ks. dz. Kazimierz Suchcicki (szef Duszpasterstwa Katolickiego OK IV) poświęcił nowe koszary. Następnie w sali Straży Ogniowej przy ul. Pałacowej 5 (obecnie ul. POW) odbył się obiad żołnierski, po którym zaproszeni goście udali się na dalszą część uroczystości do Ratusza. Od czasu przybycia II dywizjonu 4. pac do Tomaszowa Mazowieckiego żołnierz polski stał się ponownie stałym elementem życia społeczności tomaszowskiej47.

Nowe koszary, zbudowane w lesie na północ od drogi wylotowej w kierunku Piotrkowa Trybunalskiego, były nie tylko nowoczesne, ale - jak to określił Piotr Zarzycki - „niemal luksusowe: parkiety w budynkach mieszkalnych - co zdecydowało o wprowadzeniu kapci dla szeregowych, elegancko umeblowane i udekorowane obrazami świetlice, obszerne umywalnie $z$ natryskami. Wybudowano nowoczesny warsztat rusznikarsko-puszkarski, w którym był sprzęt umożliwiający nawet naprawę haubic $155 \mathrm{~mm}$. Obszerny plac ćwiczeń i nowoczesna strzelnica dopełniały obrazu tego kompleksu"48. Był on - jak wcześniej podano - dostosowany do wymogów obrony przeciwlotniczej, a działownie miały konstrukcję ogniotrwałą. Nic więc dziwnego, że w 1938 r. Departament Artylerii zalecił jednostkom artylerii, by podczas budowy nowych lub przebudowy starych działowni wzorowano się na obiektach wzniesionych w Tomaszowie Mazowieckim ${ }^{49}$.

Od czasu zakwaterowania II dywizjonu 4. pac w Tomaszowie każdorazowy jego dowódca sprawował także funkcję komendanta tutejszego garnizonu. Poczatkowo był nim mjr R. Ostrihansky dowodzacy dywizjonem od 12 lutego $1932 \mathrm{r}$. W połowie $1937 \mathrm{r}$. został zastępca dowódcy 4. pac, a stanowisko dowódcy II dywizjonu i komendanta garnizonu objął w sierpniu mjr Jan Szuster (awansowany 19 marca 1939 r. do stopnia podpułkownika) - oba stanowiska zajmował do czasu mobilizacji dywizjonu. W latach 1935-1939 zmiany objęły także dowódców obu baterii, gdyż kpt. J. Kopacza na stanowisku dowódcy 4. baterii zastapił w 1936 r.

47 Odezwa Antoniego Raczaszka przewodniczącego Obywatelski Komitet Przyjęcia Dywizjonu 4. pac z początku listopada 1935 r. i Pismo dowódcy II dywizjonu 4. pac do Rady Miejskiej w Tomaszowie Maz. z 8 XI 1935 r., APT, Zbiór akt różnych, sygn. 277 , teczka 10 , nlb.

48 P. Z a rzycki, op. cit., s. 13.

49 R. Ło ś, op. cit., s. 264. 
por. Juliusz Zapała (awansowany 19 marca 1939 r. do stopnia kapitana), a kpt. W. Cara na stanowisku dowódcy 5 . baterii pod koniec 1935 r. zastapił kpt. Aleksander Poźniak, a następnie w 1937 r. kpt. Stanisław Leszczyński, dowodzący nią przez kolejne dwa lata.

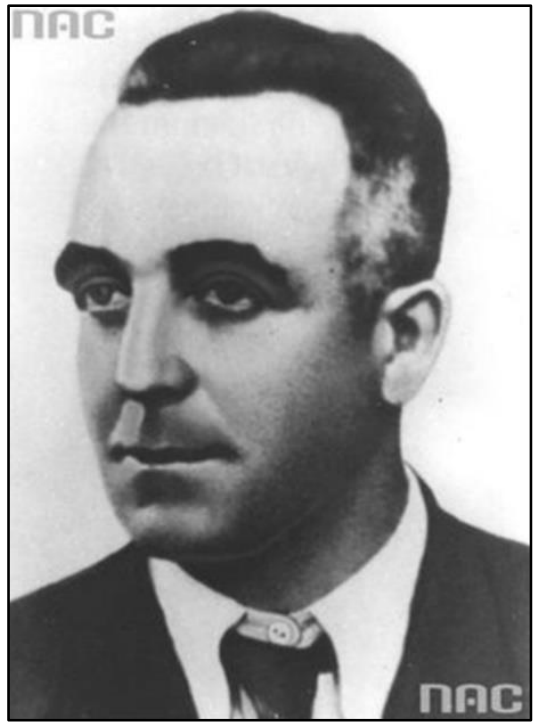

5. Ppłk Rudolf Ostrihansky, dowódca II dywizjonu 4. pac w Tomaszowie Mazowieckim, zdjęcie późniejsze Źródło: Narodowe Archiwum Cyfrowe.

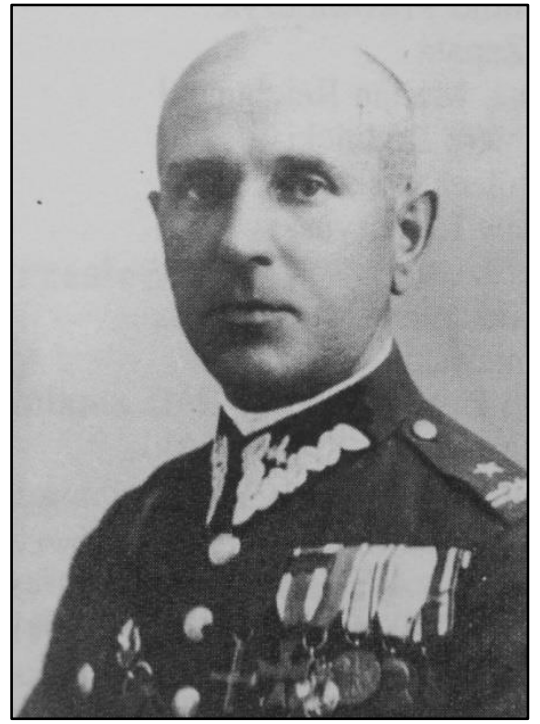

6. Ppłk Jan Szuster, dowódca II dywizjonu 4. pac w Tomaszowie Mazowieckim, zdjęcie wcześniejsze Źródło: P. Zarzy cki, 4 Pułk Artylerii Ciężkiej, Pruszków 1999, s. 24.

Służba w artylerii trwała 18 miesięcy i była podzielona na trzy sześciomiesięczne okresy. W pierwszym, tzw. okresie rekruckim, żołnierze byli szkoleni w musztrze, jeździe konnej i obsługiwaniu dział oraz dzieleni na specjalności. Następnie doskonalili swe umiejętności przez pięć kolejnych miesięcy - wspólnie ze starszym rocznikiem - według określonych specjalności oraz ćwiczyli zgranie baterii i dywizjonu w jedną całość. W owym czasie odbywały się ćwiczenia w terenie, połączone ze szkołą ognia, która była sprawdzianem wyszkolenia danej jednostki artylerii. Dwunasty miesiąc służby szeregowych służył do organizowania kursów instruktorów, którzy mieli szkolić nowy rocznik. Ostatnie sześć miesięcy polegało, podobnie jak w piechocie, na doskonaleniu zdobytych umiejętności oraz pełnieniu służby wartowniczej i administracyjno-gospodarczej. 
Praktycznym sprawdzianem opanowania umiejętności przez żołnierzy-artylerzystów były tzw. szkoły ognia oraz zawody międzybateryjne. Dla przykładu: w zawodach takich rozegranych w $1937 \mathrm{r}$. w Łodzi - na sześć baterii 4. pac - 4. bateria zajęła II miejsce, a 5. bateria - V miejsce50.

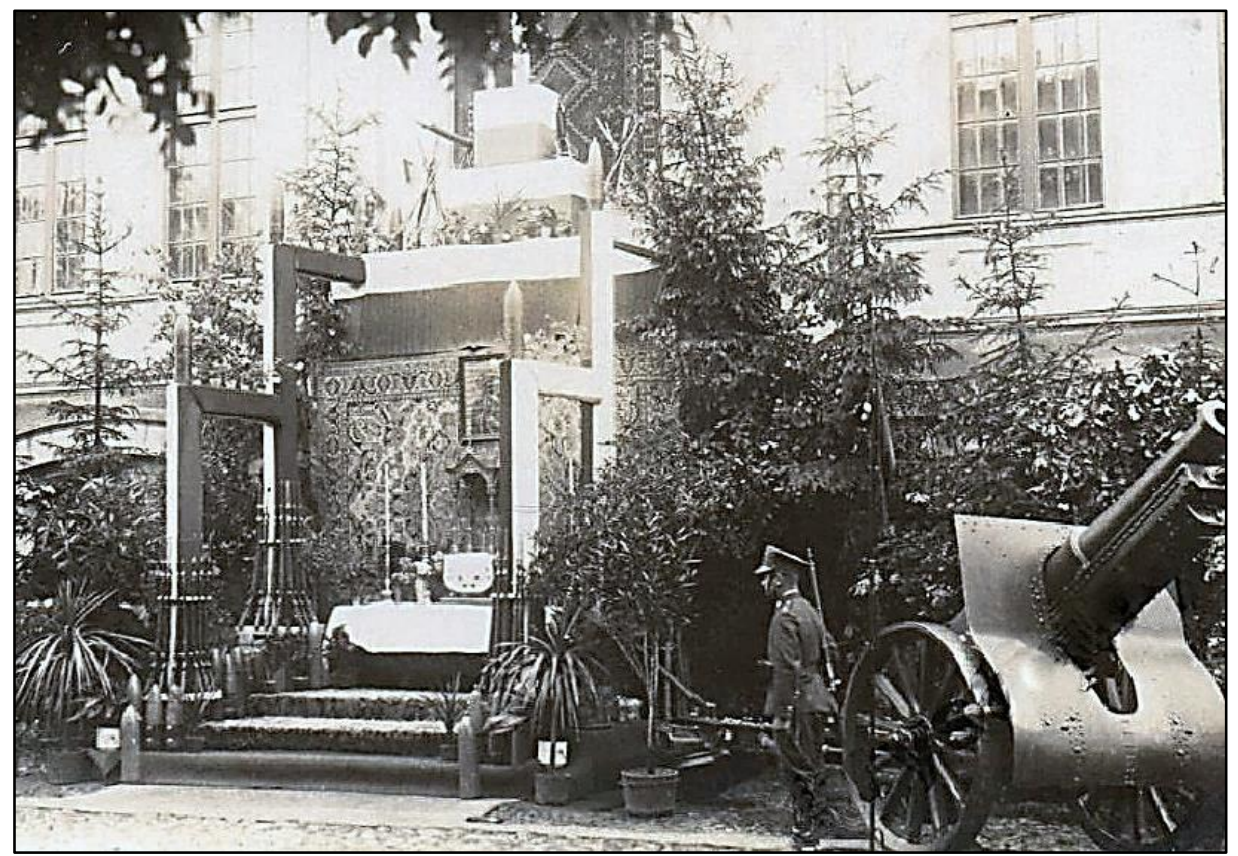

7. Ołtarz zbudowany przez żołnierzy II dywizjonu 4. pac przy budynku Straży Ogniowej na ul. POW w Tomaszowie Mazowieckim z okazji Bożego Ciała, 11 czerwca 1936 r. (ze zbiorów Wiesława Strzeleckiego)

Oprócz szkolenia żołnierze uczestniczyli również w licznych uroczystościach $z$ okazji świąt wojskowych, państwowych i religijnych. Szczególny charakter miały święta 3 maja i 11 listopada, w których żołnierze II dywizjonu uczestniczyli w odświętnym umundurowaniu. Udział wojska w tych uroczystościach był dość podobny, toteż można go przedstawić na przykładzie obchodów 3 maja w 1938 r. Zaczęły się tradycyjnie capstrzykiem w postaci wieczornego przemarszu wojska głównymi ulicami miasta w przeddzień święta. Zbiórka odbyła się o godzinie 19.00 przy zbiegu ulic Wojciechowskiego i Pierackiego (obecnie skrzyżowanie ul. Warszaw-

50 Rozkaz dowództwa 4 pac nr 29 z 7 II 1938 r., CAW, 4 pac, sygn. I.322.51, teczka 32, nlb. 
skiej z ul. Grota-Roweckiego). Stąd przy akompaniamencie orkiestry tomaszowskiej Straży Ogniowej żołnierze przemaszerowali przez Rynek Kościuszki - pod pomnik legionistów przy zbiegu dzisiejszych ulic Piłsudskiego i Legionów. Tu odczytany został uroczysty rozkaz dowódcy dywizjonu ppłk. J. Szustera, po czym kolumna żołnierska powróciła do pobliskich koszar. Następnego dnia o godzinie 9.30 odbyła się zbiórka żołnierzy obu baterii przy kościele pw. Najświętszego Serca Jezusowego, po czym - po raporcie - wzięli oni udział we mszy świętej. Następnie przemaszerowali głównymi ulicami miasta, docierając do placu T. Kościuszki, skąd powrócili ul. Piłsudskiego do koszar. Tam po uroczystym obiedzie brali udział w zawodach sportowych oraz wieczornej zabawie51.

W sferze świąt wojskowych dla żołnierzy II dywizjonu 4. pac najważniejsze było święto pułkowe obchodzone początkowo 15 maja, a od 1938 r. - 15 czerwca. Miało ono swój specjalny program i szczególna oprawę, a przygotowania do niego trwały zazwyczaj kilka tygodni i były połaczone $z$ cyklem pogadanek o tradycjach bojowych jednostki. Rokrocznie schemat święta pułkowego powielał się: poranna msza, uroczysta defilada, a następnie wspólne zabawy i zawody, ze współudziałem miejscowej społeczności oraz przedstawicieli władz lokalnych. Nie mniej uroczyście obchodzono złożenie przysięgi, którą składali rekruci wcieleni do dywizjonu. Do maja 1938 r. składano ja „na działo”, a dopiero od tego czasu na sztandar, który 4. pac otrzymał 26 maja tego roku w Warszawie. Sztandar pułku został ufundowany przez ludność powiatu brzezińskiego i mieszkańców Tomaszowa Mazowieckiego, a na stałe był przechowywany w Łodzi w dowództwie 4. pac przy ul. 6 Sierpnia 84/86. Po przywiezieniu sztandaru do Łodzi odbyła się - prawdopodobnie w czerwcu - dodatkowa uroczystość w Tomaszowie Mazowieckim, na której dokonano jego wręczenia żołnierzom II dywizjonu, po której sztandar powrócił do Łodzi. Warto dodać, że przetrwał on wojnę i znajduje się dzisiaj w Muzeum Wojska Polskiego w Warszawie52.

Ważną rolę $z$ życiu dywizjonu odgrywały także sport oraz działalność kulturalno-oświatowa. Dowództwo dywizjonu podjęło w tym zakresie współpracę $\mathrm{w}$ miejscowymi władzami i lokalnymi organi-

51 Rozkaz dowództwa II dywizjonu nr 91 z 29 IV 1938 r., CAW, 4 pac, sygn. I.322.51, teczka 42, nlb.

52 K. S a t o r a, Opowieści wrześniowych sztandarów, Warszawa 1990, s. 328329. 
zacjami, organizując dla żołnierzy wyjścia do kina czy na imprezy masowe o charakterze kulturalnym. Istotna rolę odgrywały także świetlice (istniały przy każdej baterii), gdzie żołnierze mogli spędzać wolny czas, czytając książki, prasę bieżąca i fachową (np. "Przeglad Artyleryjski”), grając w np. karty, szachy, warcaby itp. czy słuchając audycji radiowych. Prowadzono w nich także zajęcia $z$ przymusowego nauczania dla żołnierzy-analfabetów obejmujące program szkoły powszechnej. Wiele wysiłku wkładano również w rozwój wiedzy o spółdzielczości wśród żołnierzy. Oto, co na ten temat napisał P. Zarzycki: „Podobnie w II dywizjonie w Tomaszowie Mazowieckim $z$ inicjatywy mjr. Szustera prowadzono stałe kursy z zakresu spółdzielczości wiejskiej, a wykładowcami byli nauczyciele tomaszowskiej szkoły handlowej. Uczono zasad handlu, księgowości, prawa handlowego, gospodarki magazynowej itp. Praktykę szeregowcy odbywali w sklepie spółdzielczym, którego obsługa i zarząd zmieniały się często, aby jak największa liczba chętnych nabrała doświadczenia" 53 . W celu pozyskania środków finansowych na potrzeby działalności oświatowo-kulturalnej dywizjon prowadził drobną działalność gospodarczą w postaci przyjmowania przez warsztaty i kuźnie w wolnych chwilach zleceń od cywilnej ludności, wypożyczania wozów taborowych i bryczek oraz sprzedawania końskiego nawozu.

Warto jeszcze wspomnieć o zamyśle zmotoryzowania 4. pac i utworzenia doświadczalnego dywizjonu zmotoryzowanego w Tomaszowie Mazowieckim. Pułk miałby się składać jedynie $z$ dwóch dwubateryjnych dywizjonów, a nadwyżki w postaci II dywizjony 4. pac planowano zmotoryzować $z$ wykorzystaniem ciagników rolniczych i usamodzielnić, a następnie przeformować na 7. Dywizjon Artylerii Ciężkiej dla 7. Dywizji Piechoty. Jednak referat w tej sprawie opracowany przez ppłk. dypl. Zdzisława Grzymirskiego z Departamentu Artylerii nie został zaakceptowany ${ }^{54}$.

Wzrost napięcia w Europie na początku 1939 r. doprowadził 23 marca do podjęcia przez polskie władze decyzji o przeprowadzeniu częściowej mobilizacji wojska i powołaniu dowództw przyszłych zwiąków operacyjnych I rzutu (jednym z nich była Armia „Łódž" dowodzona przez gen. dyw. Juliusza Rómmla). Mobilizacja marco-

53 P. Z a r zy c ki, op. cit., s. 16.

54 Referat ppłk. dypl. Zdzisława Grzymirskiego dotyczacy reorganizacji artylerii ciężkiej w latach 1938-1940 z maja 1938 r., CAW, Departament Artylerii, sygn. I.300.34, teczka 63, nlb. 
wa objęła w OK IV skierniewicka 26. Dywizję Piechoty i stacjonujaccy w Tomaszowie Mazowieckim II dywizjon 4. pac (dywizjon był zaliczony do tzw. jednostek czarnych, co oznaczało, że w czasie pokoju był przewidywany do zadań o charakterze interwencji specjalnej lub - jak to było w tym przypadku - do osłony zagrożonej granicy państwowej) ${ }^{55}$. Istniejący w czasie pokoju 4. pac miał $\mathrm{w}$ trakcie mobilizacji - podobnie jak pozostałe pułki artylerii ciężkiej - ulec likwidacji, a na jego bazie planowano sformować kilka nowych jednostek. Jedynie II dywizjon nie został przeformowany, lecz rozbudowany do etatu wojennego przewidujacego trzy baterie. Dywizjon miał osiagnać gotowość marszową w ciagu 60 godzin od rozpoczęcia mobilizacji, czas ten dla 4 . baterii określono na 32 godziny, dla 5 . baterii - na 40 godzin, dla dowództwa dywizjonu - na 48 godzin, a dla nowo sformowanej 6 . baterii i kolumny amunicyjnej dywizjonu - na 60 godzin 56.

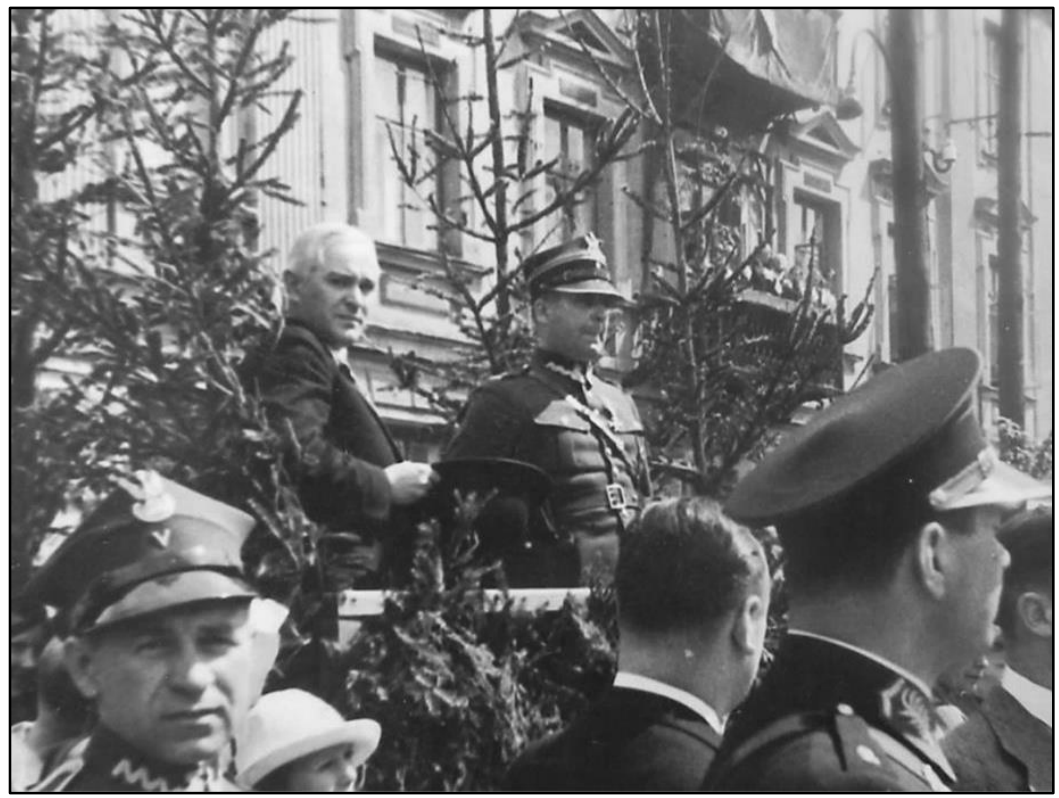

8. Podpułkownik Jan Szuster na trybunie honorowej na placu Tadeusza Kościuszki w Tomaszowie Mazowieckim, około 1938/1939 r. (ze zbiorów Krzysztofa Zakrzewskiego)

55 O przygotowaniach obronnych i pracach mobilizacyjnych w OK IV w $1939 \mathrm{r}$. Szerzej: W. J a r n o, Okreg Korpusu..., s. 303-358.

56 R. Ry b k a, K. S t e p a n, Najlepsza broń. Plan mobilizacyjny „W” i jego ewolucja, Warszawa 2010, s. 327. 
Obsada II dywizjonu 4. pac z 1 września 1939 r.

\begin{tabular}{|l|l|}
\hline \multicolumn{1}{|c|}{ Stanowisko } & \multicolumn{1}{c|}{ Obsada personalna } \\
\hline - dowódca dywizjonu & ppłk Jan Szuster \\
- adiutant dowódcy dywizjonu & por. rez. Stefan Dembiński \\
- oficer zwiadowczy & por. rez. Jerzy Mirowski \\
- oficer obserwacyjny & por. Zygmunt Jeger \\
- oficer łączności & ppor. rez. Zenon Marliński \\
- oficer płatnik & ppor. rez. Stanisław Pawelczak \\
- oficer żywnościowy & ppor. rez. Henryk Rożniecki \\
- lekarz dywizjonu & ppor. rez. lek. Gabriel Hertz \\
- lekarz weterynarii & ppor. rez. lek. wet. Edward Folta \\
- dowódca kolumny amunicyjnej & por. rez. Witold Piwowarczyk \\
- dowódca 4. baterii & kpt. Julian Zapała \\
- oficer zwiadowczy baterii & ppor. rez. Marian Reichundel \\
- oficer ogniowy baterii & ppor. Kazimierz Rudnicki \\
- dowódca I plutonu & ppor. Jan Bolechowski \\
- dowódca 5. baterii & kpt. Stanisław Leszczyński \\
- oficer zwiadowczy baterii & pchor. Przeździecki (imię nieznane) \\
- oficer ogniowy baterii & ppor. rez. Kazimierz Myczka \\
- dowódca I plutonu & pchor. Wiśniewski (imię nieznane) \\
- dowódca 6. baterii & por. Edward Pawlikowski \\
- oficer zwiadowczy baterii & ppor. rez. Franciszek Komorowski \\
- oficer ogniowy baterii & ppor. Stefan Janczyk \\
- dowódca I plutonu & ppor. Jan Wilczek \\
\hline
\end{tabular}

Źródło: P. Zarzy cki, 4 Pułk Artylerii Ciężkiej, Pruszków 1999, s. 22-23; M. B i e 1s k i, Grupa Operacyjna „Piotrków” 1939, Warszawa 1991, s. 366-367.

Dzięki wysiłkom kadry oficerskiej dywizjonu w ciagu kilku dni udało się rozwiązać większość trudności, co pozwoliło zakończyć mobilizację $\mathrm{w}$ przewidzianym terminie. Już 26 marca istniejące w czasie pokoju dwie baterie (4. - dowodzona przez por. J. Zapałę - i 5. - dowodzona przez kpt. S. Leszczyńskiego) osiagnęły gotowość bojowa i zostały przeniesione do wsi Zawada pod Tomaszowem Mazowieckim (obecnie dzielnica miasta). W ciagu trzech dni sformowano także nową 6. baterię, której dowództwo objął por. E. Pawlikowski (wcześniej dowódca plutonu w szkole podoficerskiej 4. pac). W przewidzianym terminie zmobilizowano również kolumnę amunicyjna dowodzona przez por. rez. Józefa Piwowarczyka i dowództwo dywizjonu. Po zakończeniu mobilizacji II dywizjon 4. pac - mający teraz trzy czterodziałowe baterie uzbrojone w 12 haubic $155 \mathrm{~mm}$ wz. 17 - został podporządkowany dowódcy 
30. Dywizji Piechoty gen. bryg. Leopoldowi Cehakowi i w połowie maja przegrupowany w rejon Bełchatów-Działoszyn-Szczerców. W czerwcu dywizjon skierowano do prac fortyfikacyjnych na odcinku Armii „Łódž”, a po wybuchu wojny wspierał ogniem wspomniana dywizję57.

W opuszczonych przez II dywizjon koszarach 26 marca 1939 r. utworzono Ośrodek Zbierania Nadwyżek II dywizjonu 4. pac pod dowództwem kpt. Hipolita Burcharda, który objał zarazem stanowisko komendanta garnizonu. Jego zastępca został por. rez. Stefan Terlecki. Przez kilka kolejnych miesięcy życie w koszarach podobnie jak w mieście - toczyło się normalnym trybem, choć w końcu sierpnia dawało się odczuć atmosferę niepokoju i narastającej groźby wybuchu wojny. Około 27 sierpnia $z$ rozkazu kpt. H. Burcharda $z$ uczniów szkół średnich mających przeszkolenie wojskowe sformowano kompanię Obrony Narodowej, która pomagała w pełnieniu służby wartowniczej i patrolowej na terenie Tomaszowa Mazowieckiego. Po wybuchu wojny do koszar zaczęli się masowo zgłaszać rezerwiści, $z$ których miano formować uzupełnienia dla własnego pułku. Prace te prowadzono do wieczora 5 września, gdy kpt. H. Burchard otrzymał rozkaz natychmiastowego wymarszu całego Ośrodka Zbierania Nadwyżek II dywizjonu 4. pac do Warszawy. W tamtym też kierunku udała się kompania Obrony Narodowej dowodzona przez por. rez. S. Terleckiego. W rejonie Rawy Mazowieckiej oba te oddziały zostały zbombardowane przez niemieckie samoloty, lecz nie przeszkodziło to im w dotarciu do stolicy. Tu kpt. H. Burchard otrzymał rozkaz dalszego marszu w kierunku Kowla, gdzie po agresji sowieckiej oddział został rozwiązany58.

Na zakończenie trzeba dodać, że 6 września Tomaszowa Mazowieckiego bohatersko bronił 45. Pułk Strzelców Kresowych z 13. Dywizji Piechoty, który w trakcie nocnego odwrotu w kierunku Lubochni uległ rozproszeniu w wyniku nocnej dywersji niemieckiej V kolumny w rejonie ul. Warszawskiej. Następnego dnia rano do miasta wkroczyły odziały niemieckiej 1. Dywizji Pancernej, co zapoczątkowało ponad pięcioletni okres okupacji niemieckiej. Garni-

57 Rozkazy II dywizjonu z 1939 r., CAW, 4 pac, sygn. I.322.51, teczka 43; Relacja ppłk. dypl. Jana Szewczyka, ibidem, Kampania wrześniowa, sygn. II.3.13., k. 198-200; P. Zarzycki, op. cit., s. 22-23; W. J a r n o, Okręg Korpusu..., s. $312-313$.

58 P. Zarzycki, op. cit., s. 49-51. 
zon tomaszowski odrodził się w 1945 r. i do dziś stanowi istotny element w życiu miasta, a stacjonująca w nim obecnie 25. Brygada Kawalerii Powietrznej do dziś wykorzystuje dawne - choć oczywiście rozbudowane i zmodernizowane - koszary przedwojennego II dywizjonu 4. pac.

WITOLD JARNO

\section{A contribution to the history of Tomaszów Mazowiecki during the period of the II Polish Republic}

The article describes the history of the Polish Army garrison in Tomaszow Mazowiecki in years 1918-1939. In November 1918, the German infantry company was disarmed, what started the history of Polish garrison in this city. Quickly was formed a troop, which in January 1919 were incorporated into formed in Lodz the first Battalion of the 28th Infantry Regiment. In the summer of 1919 were moved from Brzeziny to Tomaszow: Military Replenishment Command and Field Replacement Battalion of the 30th Infantry Regiment. Year later arrived in the Tomaszow the second battalion of this regiment, which in 1924 was moved to Warsaw. In the same year arrived to Tomaszow the second Battalion of the $25^{\text {th }}$ Infantry Regiment, which three years later was reorganized at the Reserve Officers Training Centre No. 4. This school existed until 1929. Then, for the next six years at Tomaszow didn't stationed military units. Garrison was re-created in the autumn 1935. At the time, arrived in the city the second battalion of the $4^{\text {th }}$ Heavy Artillery Regiment, which there stationed until the outbreak of war. This military unit was quartered in modern barracks built in the mid-thirties. In March 1939 the second battalion of the 4th Heavy Artillery Regiment was mobilized and directed to the Army "Lodz". In the abandoned barracks was created reserve center, which existed until $5^{\text {th }}$ September. Two days later Tomaszow Mazowiecki was occupied by the German army, what ended the history of Polish garrison in the interwar period. 